Article

\title{
Sustainable Buildings' Energy-Efficient Retrofitting: A Study of Large Office Buildings in Beijing
}

\author{
Shiyu Wan ${ }^{1,2} \mathbb{D}$, Grace Ding ${ }^{2}$, Goran Runeson ${ }^{2}$ and Yisheng Liu ${ }^{1, *}$ \\ 1 Faculty of Economics and Management, Beijing Jiaotong University, Beijing 100044, China; \\ fishwansy@163.com or shiyu.wan@student.uts.edu.au \\ 2 Faculty of Design, Architecture and Building, University of Technology Sydney, Ultimo 2007, Australia; \\ Grace.Ding@uts.edu.au (G.D.); karl.runeson@uts.edu.au (G.R.) \\ * Correspondence: yshliu1@bjtu.edu.cn
}

check for updates

Citation: Wan, S.; Ding, G.; Runeson, G.; Liu, Y. Sustainable Buildings' Energy-Efficient Retrofitting: A Study of Large Office Buildings in Beijing. Sustainability 2022, 14, 1021. https:/ / doi.org/10.3390/su14021021

Academic Editor: Francesco Asdrubali

Received: 10 December 2021

Accepted: 13 January 2022

Published: 17 January 2022

Publisher's Note: MDPI stays neutral with regard to jurisdictional claims in published maps and institutional affiliations.

Copyright: (C) 2022 by the authors. Licensee MDPI, Basel, Switzerland. This article is an open access article distributed under the terms and conditions of the Creative Commons Attribution (CC BY) license (https:// creativecommons.org/licenses/by/ $4.0 /)$.
Abstract: Energy-efficient retrofitting has emerged as a primary strategy for reducing the energy consumption of buildings. Buildings in China account for about $40 \%$ of total national energy consumption. Large office buildings account for the most. Less than $5 \%$ of the building area of existing office buildings is energy efficient. Energy-efficient retrofitting for sustainable buildings is a complicated system that involves various sustainable dimensions and operational technical schemes. Making multi-criteria decisions becomes a challenging problem for stakeholders. Based on the theory of sustainability, this paper establishes a sustainable analysis framework to guide stakeholders to select an optimal technical combination of energy-efficient retrofit measures for large office buildings. Based on empirical data collected in Beijing, a number of energy efficiency measures are selected, tailored and applied to a virtual model of a typical large office building. Technical features and the energy performance are simulated accordingly. The energy consumption, energy-saving ratio and lifecycle costs are derived to identify the optimal configuration. The outcome of this research offers a feasible technical plan for stakeholders relating to technical design and design making. The study finds that an LED lighting system and frequency conversion device for the cooling water chiller cannot only sufficiently reduce the building's energy consumption but also perform economically. Different thermal insulation materials for reconstructing the building envelope have no obvious effect on the thermal performance in comprehensive simulations of technology combinations. The sustainable analysis framework offers theoretical and practical support and can be used as a reference for the other types of buildings in future research.

Keywords: energy-efficient retrofitting; large office building; building energy-efficiency technologies (BEETs); sustainability; lifecycle cost; multi-criteria decisions

\section{Introduction}

Climate change is a challenge all over the world. Responding to climate change, China has pledged to considerably reduce its $\mathrm{CO}_{2}$ emissions to reach carbon peak before 2030 and achieve carbon neutrality before 2060 [1]. When considering buildings' energy efficiency, existing buildings can play an important role in energy conservation and emission reduction [2]. Energy consumption in buildings accounts for nearly $40 \%$ of the total primary energy consumption in China [3]. Public buildings (in China, these are not limited to government-owned properties but also include office buildings; hotels; commercial buildings; science, education, culture and health buildings; communication buildings and transportation buildings [4]) account for approximately one-fifth of the total energy consumption of buildings [4,5]. Existing office buildings occupy about 4.5 billion square meters of total floor area, and less than $5 \%$ of floor area achieves the required energy efficiency [6]. Energy consumption in existing office buildings is markedly high in terms of heating, cooling, ventilation and lighting. Especially in northern China, winter heating 
and summer cooling consume a lot of energy. Besides this, the heat produced by a large amount of office equipment means the energy load of office buildings is higher than those of other types of buildings. Therefore, existing office building retrofits have great potential for improving energy efficiency in the building sector, which could help with meeting the overall nationwide energy efficiency objectives, aimed at reducing the country's energy consumption and the associated negative environmental impacts.

Applying building energy-efficiency technologies (BEETs) is the most effective way to achieve energy savings for existing buildings $[3,7,8]$. The common energy-efficiency technologies are: reconstruction of building envelope, highly efficient lighting systems and heating, ventilation and air conditioning (HVAC) systems [4]. These technologies show good energy-saving performance according to the analysis and simulation of different aspects of energy consumption [3,4,9]. However, there are some interactions among different kinds of BEETs, which may have a great influence on the final energy-saving effect $[10,11]$. Meanwhile, most of the research about BEETs focuses on the energy performance of a particular technology but not the overall energy performance when integrating all types of BEETs [12-14]. In addition, from the perspective of stakeholders, architects, designers and engineers are enthused by retrofitting technologies and schemes. Building owners, though, who are the key decision-makers in energy-efficient retrofits, care more about the costs and benefits of building energy conservation [15]. Balancing multiple factors that achieve the highest energy-saving performance and the least retrofitting cost represents a significant challenge for stakeholders.

To address the above research gap and encourage the market to conserve energy through existing buildings, it is important to establish a comprehensive and systematic method to select feasible energy-efficiency technologies and measure their integrated performance. This study aimed to develop a holistic and comprehensive analysis method integrating technology, energy and the economic effect, to offer stakeholders a reference for how best to select a feasible technical scheme based on multi-criteria.

Many research projects have been carried out on BEETs. Boyano et al. selected three climate zones in Europe, then created a typical model in each of the local areas using the software EnergyPlus. The researchers calculated buildings' energy consumption under three different settings for the envelope, illumination density and lighting control, and finally proposed feasible technology measures suitable for the three climate zones [11]. Moncef et al. comparatively evaluated the optimal energy-efficiency designs for French and US office buildings [16]. Baranova et al. analyzed buildings' energy performance across the Baltic Sea region, to investigate the influence of local building norms on buildings energy consumption [17]. However, the typical models developed in the above research are limited to a local context because they use local indexes. Ibrahim et al. developed an integrated classification methodology for retrofitting heritage residential buildings in Khedivial, Cairo by connecting retrofitting strategies with that classification of buildings [18]. Pasichnyi et al. established a data-driven approach to create energy retrofitting strategies at the city level [19]. Pardo-Bosch et al. compared three major retrofitting interventions in three European cities, which each aimed at achieving a sustainable city [20]. These last two approaches to achieving sustainability at a city level were more beneficial to urban planners or the government than those before.

Further researchers conducted economic analyses of retrofitting technologies. Qichen et al. conducted an economic analysis of three aspects of energy-saving renovation-the envelope heat insulation, building shading and natural ventilation-based on a residential building located in Xiamen, China [21]. By involving the concept of the lifecycle, Shadram et al. compared the optimal retrofitting solutions to achieve newbuild near-zero energy standards in Sweden [22]. Ren et al. carried out lifecycle financial evaluation, which can be used for an economic index of building energy-saving retrofits [23]. Although the need for and potential benefits of energy retrofits have been well-documented, the pace of adoption of energy-efficient practices and technologies has been slow, and significant barriers—both perceived and actual—persist in limiting building energy investments [24,25]. 
Kurnitski et al. conducted a study on cost-optimal solutions for residential and office buildings; they calculated the labor, material and construction costs, but did not consider the maintenance cost. Those studies gave clear retrofitting technology cost calculation methods, but they all tended toward a basic cost and technical-economic analysis [26]. Paolo et al. illustrated how to cost-design nZEBs for a warm climate in Italy, selecting the most efficient combination of energy-saving technologies [27]. Yang et al. built a typical office and commercial building model for three locations-Beijing, Shanghai and Guangzhou-using the software EnergyPlus and calculated the energy-saving ratio and economic efficiency, then proposed technology selections [28]. Kim carried out an economic analysis of energysaving technologies for complex manufacturing buildings, and the return on investment was determined by using payback analysis and lifecycle cost analysis [29]. Egiluz et al. developed a multi-criteria decision-making method for retrofitting based on the concept of sustainability [30].

Almost all of the existing research on office building energy conservation technology focused on the overall energy-saving effect and economic benefit, and less on the need to integrate adoption of technology with the need to be economical. Furthermore, most research has focused on new buildings. The objective of this paper is to discuss energy-saving retrofitting technologies that can be applied to existing large office buildings. After defining a baseline reference building, a typical large office building energy consumption model in Beijing was built. Several technical variants were selected and applied. Energy-saving ratio and lifecycle retrofitting cost calculations were made for the obtained configurations, to determine the maximum energy-saving effect and minimum cost. A financial and macroeconomic study was carried out to establish the cost-optimal technology combinations and optimum energy-saving effect.

According to an analysis of the existing literature, most research has been on the application of energy-efficiency technologies to different types of buildings and different climate regions in the United States and Europe, or focused on optimizing the approach to building energy-efficiency strategies in different scenarios. These studies offer a reference for the processes that can be applied to evaluate BEETs. Yet, most of the research findings are more useful for specific countries and regions because of corresponding area indexes and data supports in the economic evaluation. In China, there is little research on integrated energy-efficiency technologies for buildings in different climate zones, and there is a lack of systematic research on energy-efficiency strategies applying a typical city-level building model. It is necessary to develop a typical building model considering the climate zones in China. Yet, there are some difficulties with conducting a comprehensive technical-economic analysis, which have created obstacles to promoting building energy efficiency in China.

This study took large office buildings in Beijing as an example and developed an operational framework for sustainable, energy-efficient building retrofits. It used a mixedmethods research approach. Empirical data on retrofitting demonstration cases for Beijing's existing office buildings and Chinese building energy conservation statistics report were applied to construct a virtual model of a physical building representing a typical large office building in Beijing. This simulated the building's energy performance when combining technologies in different systems. In this way, the comprehensive energy performance after retrofitting could be simulated by considering the interactions of different energy systems. The model was then combined with a conceptual framework of sustainability to discuss how to select an optimal technological combination to achieve lower lifecycle costs. A quantitative paradigm set the basis for this research, with qualitative perspectives integrated to develop the operational framework. An economic analysis was conducted by estimating the initial retrofitting investments, related payback periods and other economic indicators. The inclusion of lifecycle costs in the economic analysis brought an innovative perspective as it took the lifecycle of each system into consideration, which allowed the total costs of energy consumption and operation to be largely predicted.

This research (1) measured which type of the technical scheme had great energy-saving potential; (2) calculated how the energy-saving benefits offset the energy consumption 
costs and the payback period; and (3) offers stakeholders a reference for which type of energy-efficient retrofit measures to focus on and how to choose a feasible energy-efficient retrofitting scheme. The process for achieving these objectives offers a holistic operational framework for evaluating feasible technical schemes, considering the interactions of different energy systems and their lifecycle costs. The results of this research add new information on energy-efficient retrofitting for office buildings. This will facilitate future action to reduce China's energy consumption and operational costs. This research could act as a reference for other types of buildings and regions.

\section{Methodology}

\subsection{Definition of the Research Scope}

Office buildings refer to the office premises of enterprises, public institutions, state organs, organizations, schools and hospitals, including commercial office buildings [31]. As public buildings, based on the total floor area and energy intensity except for heating, office buildings can be divided into two types: (1) large office buildings that make use of a central air-conditioning system, where a single building covers over 200,000 square meters, and (2) ordinary office buildings. According to the functions, construction area and energy consumption of the buildings, in this study, large office buildings are selected as the research subject, considering their significant energy consumption.

Existing office buildings are office buildings that have been constructed and put into use. An energy-saving retrofit of one of these transforms an energy-wasting existing office building into one that meets energy-saving requirements. The scope of such an energy-saving retrofit must comply with China's design code of building energy efficiency. This paper focuses on large office buildings built from 1981 to 2005, which do not satisfy China's "Design Standard for Energy Efficiency of Public Buildings" [5]. According to the virtual energy consumption data of existing office building retrofitting demonstration cases, the retrofits in the paper are conducted on the envelope and the heating, ventilation and air conditioning (HVAC) systems and lighting systems. Renewable energy systems are also contributing to reducing the energy consumption of fossil fuels, but the focus of this research is how to improve the energy efficiency of the current systems by consuming less energy and yet upholding the same amount of indoor environment. The options for using renewable energy systems are another type of decision-making problem; therefore, they are not considered as a part of the building energy-efficiency technologies in this paper. The purpose of this paper is to improve the energy efficiency of the current systems and evaluate the comprehensive energy performance of the improved energy-efficiency technologies. After a retrofit, the building's energy consumption should meet the minimum requirements of the latest national "Design Standard for Energy Efficiency of Public Buildings GB501892015" [5].

This research was based on simulating buildings' energy consumption before and after retrofitting. The simulation was implemented on a typical physical model of a standard large office building developed according to historical and normal information and the "Design Standard for Energy Efficiency of Public Buildings GB50189-2015" [5], including the climate conditions, indoor environment settings, operating period and settings and physical information on large office buildings in Beijing [6,32-44].

\subsection{Geographical Location}

The reference office building of this study is located in Beijing, in the north of China and cold climatic zone II. It is characterized by a monsoon climate of medium latitudes with cold and dry winters (average temperatures from $-10^{\circ} \mathrm{C}$ to $0{ }^{\circ} \mathrm{C}$ ) and hot and rainy summers (average temperatures from $20^{\circ} \mathrm{C}$ to $35^{\circ} \mathrm{C}$ ). In this area, buildings should meet the requirements of being cold-proof, heat preserving and antifreeze in winter, while also providing heat protection in summer. This research represents a typical example as a reference for similar studies in other climatic zones. 


\subsection{Typical Physical Model of Large Office Buildings in Beijing}

\subsubsection{Selection of the Modeling Method}

This research developed an operational framework for stakeholders to use to evaluate feasible technical schemes. By using simulation software, the comprehensive energy performance integrating all kinds of energy systems could be simulated to show the energysaving potential after retrofitting. Building energy simulations have been demonstrated to be efficient tools throughout a building's lifecycle to analyze the energy performance in complex scenarios [45-47]. By constructing a "typical office building", the researchers characterized the general office in terms of its space, form and thermal properties, which helps to guide energy-efficient design for this type of building. At present, there are two methods to establish a typical building model: the benchmark building method [48] (adopting a survey) and the simplified model method [49] (adopting a fitting formula). This paper used the benchmark building method to create a large office building model according to the literature on the virtual measured data for large office buildings' energy consumption in Beijing, Beijing's existing office building retrofitting demonstration cases and a Chinese building energy conservation statistics report [6,32-44]. As this research was not focused on a particular building, it based the work on a virtual building model representing a typical large office building in Beijing. The parametric data designed in the model were collected from current cases and the process of constructing a benchmark building followed a standardized method. Due to a lack of data on energy consumption after retrofits, the model could not be calibrated to be closer to a real situation. Although further calibration was not involved due to limited data access, the simulation results from the proposed model for the energy consumption before retrofitting were compared with an actual case of original energy consumption before retrofitting. The relative error was less than $10 \%$, which meant the results could be considered reliable (the results are shown at the end of Section 2.3). Detailed information about the assumptions of benchmark building modeling is introduced in the following section.

\subsubsection{Geometrical Features' and Construction Elements' Properties}

The typical existing large office building has 13 above-ground floors and two underground floors. The total floor area is about 21,751.2 square meters, and the height of each story is $4 \mathrm{~m}$. The building faces south, and on each side, the window-to-wall area ratio is about $40 \%$. The structure of the building is a tower, with the center built as a core tube, as shown in Figure 1.

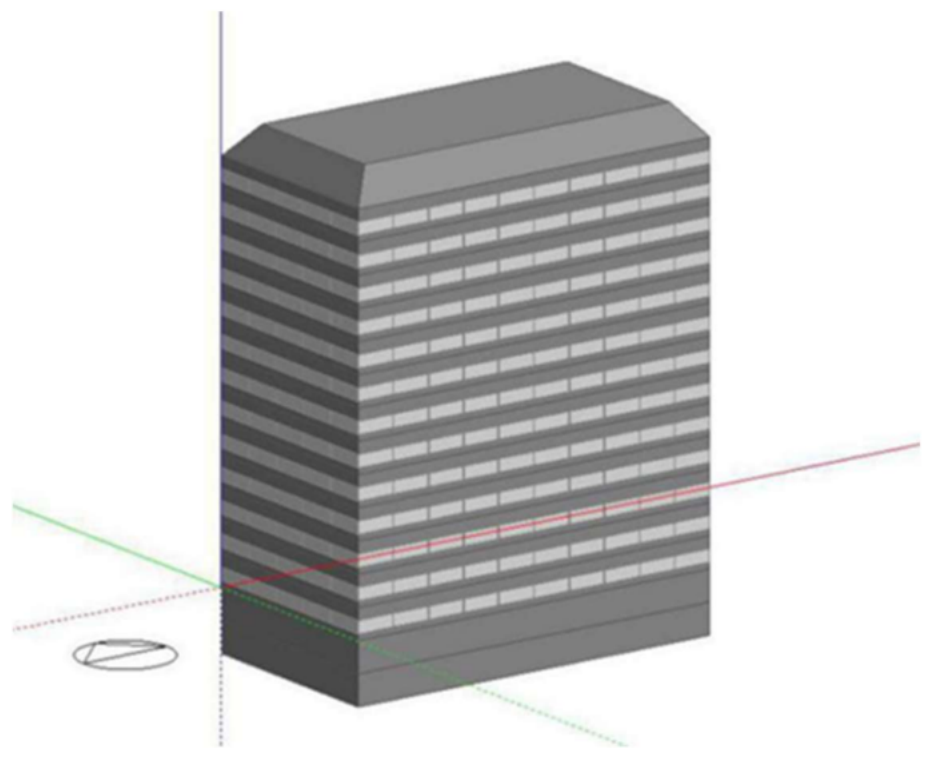

Figure 1. Typical large-scale office building model in Beijing. 
The designed temperature of the office building is $26{ }^{\circ} \mathrm{C}$ in summer and $20{ }^{\circ} \mathrm{C}$ in winter. The working hours are from 7 a.m. to 6 p.m., Monday to Friday. Information on the building operations was collected from the "Design Standard for Energy Efficiency of Public Buildings GB50189-2015" [5]. From 7 a.m. to 6 p.m., the cooling and heating are on full blast. From 6 a.m. to 7 a.m., there is partial cooling, set at a $28^{\circ} \mathrm{C}$ indoor temperature. From 5 a.m. to 7 a.m., the heating is partial, set from a $12{ }^{\circ} \mathrm{C}$ to $18{ }^{\circ} \mathrm{C}$ indoor temperature. The ventilation is switched on from 6 a.m. to 7 p.m. The artificial lighting system and electrical equipment work partially from 6 a.m. to 8 a.m. and 5 p.m.to 7 p.m., and they work fully from 8 a.m. to 5 p.m. Detailed operating information for the typical office building on working days is summarized in Table 1.

Table 1. Operating information of the typical office building on a working day.

\begin{tabular}{|c|c|c|c|c|c|c|}
\hline \multirow[b]{2}{*}{ Items } & \multicolumn{6}{|c|}{ Time Schedule } \\
\hline & $\begin{array}{l}\text { 0:00-1:00 } \\
\text { a.m. }\end{array}$ & $\begin{array}{l}\text { 1:00-2:00 } \\
\text { a.m. }\end{array}$ & $\begin{array}{l}\text { 2:00-3:00 } \\
\text { a.m. }\end{array}$ & $\begin{array}{l}\text { 3:00-4:00 } \\
\text { a.m. }\end{array}$ & $\begin{array}{l}\text { 4:00-5:00 } \\
\text { a.m. }\end{array}$ & $\begin{array}{l}\text { 5:00-6:00 } \\
\text { a.m. }\end{array}$ \\
\hline $\begin{array}{l}\text { Cooling (indoor temperature } /{ }^{\circ} \mathrm{C}, "{ }^{-} \text {" stands } \\
\text { for natural temperature) }\end{array}$ & - & - & - & - & - & - \\
\hline Heating (indoor temperature $/{ }^{\circ} \mathrm{C}$ ) & - & - & - & - & - & 12 \\
\hline Lighting (ratio of lights on/\%) & 0 & 0 & 0 & 0 & 0 & 0 \\
\hline Occupancy of the room (\%) & 0 & 0 & 0 & 0 & 0 & 0 \\
\hline $\begin{array}{l}\text { Ventilation ( } 1 \text { stands for open and } 0 \text { stands for } \\
\text { closed) }\end{array}$ & 0 & 0 & 0 & 0 & 0 & 0 \\
\hline Electrical equipment (ratio of use/\%) & 0 & 0 & 0 & 0 & 0 & 0 \\
\hline Items & $\begin{array}{l}\text { 6:00-7:00 } \\
\text { a.m. }\end{array}$ & $\begin{array}{l}\text { 7:00-8:00 } \\
\text { a.m. }\end{array}$ & $\begin{array}{l}\text { 8:00-9:00 } \\
\text { a.m. }\end{array}$ & $\begin{array}{l}\text { 9:00-10:00 } \\
\text { a.m. }\end{array}$ & $\begin{array}{l}\text { 10:00-11:00 } \\
\text { a.m. }\end{array}$ & $\begin{array}{l}\text { 11:00-12:00 } \\
\text { a.m. }\end{array}$ \\
\hline $\begin{array}{l}\text { Cooling (indoor temperature } /{ }^{\circ} \mathrm{C}, "{ }^{-} \text {" stands } \\
\text { for natural temperature) }\end{array}$ & 28 & 26 & 26 & 26 & 26 & 26 \\
\hline Heating (indoor temperature $/{ }^{\circ} \mathrm{C}$ ) & 18 & 20 & 20 & 20 & 20 & 20 \\
\hline Lighting (ratio of lights on/\%) & 10 & 50 & 95 & 95 & 95 & 95 \\
\hline Occupancy of the room (\%) & 10 & 50 & 95 & 95 & 95 & 95 \\
\hline $\begin{array}{l}\text { Ventilation ( } 1 \text { stands for open and } 0 \text { stands for } \\
\text { closed) }\end{array}$ & 1 & 1 & 1 & 1 & 1 & 1 \\
\hline Electrical equipment (ratio of use/\%) & 10 & 50 & 95 & 95 & 95 & 95 \\
\hline Items & $\begin{array}{l}\text { 12:00-1:00 } \\
\text { p.m. }\end{array}$ & $\begin{array}{l}\text { 1:00-2:00 } \\
\text { p.m. }\end{array}$ & $\begin{array}{l}\text { 2:00-3:00 } \\
\text { p.m. }\end{array}$ & $\begin{array}{l}\text { 3:00-4:00 } \\
\text { p.m. }\end{array}$ & $\begin{array}{l}\text { 4:00-5:00 } \\
\text { p.m. }\end{array}$ & $\begin{array}{l}\text { 5:00-6:00 } \\
\text { p.m. }\end{array}$ \\
\hline $\begin{array}{l}\text { Cooling (indoor temperature } /{ }^{\circ} \mathrm{C}, "{ }^{\prime} \text { " stands } \\
\text { for natural temperature) }\end{array}$ & 26 & 26 & 26 & 26 & 26 & 26 \\
\hline Heating (indoor temperature $/{ }^{\circ} \mathrm{C}$ ) & 20 & 20 & 20 & 20 & 20 & 20 \\
\hline Lighting (ratio of lights on/\%) & 95 & 95 & 95 & 95 & 95 & 30 \\
\hline Occupancy of the room (\%) & 95 & 95 & 95 & 95 & 95 & 30 \\
\hline $\begin{array}{l}\text { Ventilation ( } 1 \text { stands for open and } 0 \text { stands for } \\
\text { closed) }\end{array}$ & 1 & 1 & 1 & 1 & 1 & 1 \\
\hline Electrical equipment (ratio of use/\%) & 95 & 95 & 95 & 95 & 95 & 30 \\
\hline Items & $\begin{array}{l}\text { 6:00-7:00 } \\
\text { p.m. }\end{array}$ & $\begin{array}{l}\text { 7:00-8:00 } \\
\text { p.m. }\end{array}$ & $\begin{array}{l}\text { 8:00-9:00 } \\
\text { p.m. }\end{array}$ & $\begin{array}{l}\text { 9:00-10:00 } \\
\text { p.m. }\end{array}$ & $\begin{array}{l}\text { 10:00-11:00 } \\
\text { p.m. }\end{array}$ & $\begin{array}{l}\text { 11:00-12:00 } \\
\text { p.m. }\end{array}$ \\
\hline $\begin{array}{l}\text { Cooling (indoor temperature } /{ }^{\circ} \mathrm{C}, "{ }^{\prime} \text { " stands } \\
\text { for natural temperature) }\end{array}$ & - & - & - & - & - & - \\
\hline Heating (indoor temperature $/{ }^{\circ} \mathrm{C}$ ) & 18 & 12 & - & - & - & - \\
\hline Lighting (ratio of lights on/\%) & 30 & 0 & 0 & 0 & 0 & 0 \\
\hline Occupancy of the room (\%) & 30 & 0 & 0 & 0 & 0 & 0 \\
\hline $\begin{array}{l}\text { Ventilation ( } 1 \text { stands for open and } 0 \text { stands for } \\
\text { closed) }\end{array}$ & 1 & 0 & 0 & 0 & 0 & 0 \\
\hline Electrical equipment (ratio of use/\%) & 30 & 0 & 0 & 0 & 0 & 0 \\
\hline
\end{tabular}


Before the retrofit, the air conditioning system of the typical building adopted a fan coil unit and independent outdoor air system, which are commonly used in the domestic office building. The retrofit system was selected and calculated by the software Design Builder. The cold and heat sources were the typical combination of electric refrigerating units and gas-fired boilers. The water system was a constant-flow primary pump system. The retrofit water pump and other equipment were selected and calculated by Design Builder software. The building's retrofit needed to meet the minimum design standards of GB50189-2015 for public building energy-saving. The external walls, floor and roof had to be adjusted to meet the design standard of the "corresponding climate division" for the energy efficiency of public buildings in GB50189-2015 and the thermal performance parameters of the building envelope structure [5]. The retrofit equipment selection for the HVAC system was based on the existing typical building model, carried out following the guidelines for improving energy efficiency and completed by Design Builder software. The indoor environmental quality was considered for the model design, including the thermal comfort, indoor air quality and visual comfort [50]. The settings for the indoor temperature, occupancy, ventilation and lighting operation can be found in Table 1 . The settings for the lighting density, illumination and outdoor air quantity can be found in Table 2. In this research, energy-efficient retrofitting did not affect the indoor environmental quality, neither thermally nor visually, and the settings were regulated as shown in Table 2 . Specific values for the indoor loads-for lighting, equipment and personnel, as determined by reference to relevant national standards [5,51]—are shown in Table 2.

Table 2. Model parameters of typical large office building in Beijing.

\begin{tabular}{ccc}
\hline Benchmark Model Parameter & Status before Retrofit & Status after Retrofit \\
\hline Lighting density $/ \mathrm{W} / \mathrm{m}^{2}$ & 11 & 11 \\
\hline Illumination $/ \mathrm{Lux}$ & 350 & 18 \\
\hline Equipment power $/ \mathrm{W} / \mathrm{m}^{2}$ & 17.5 & 6 \\
\hline Personnel density $/ \mathrm{m}^{2} / \mathrm{people}$ & 6 & 2.7 \\
\hline $\begin{array}{c}\text { Window heat transfer } \\
\text { coefficient } / \mathrm{W} /\left(\mathrm{m}^{2} \mathrm{~K}\right)\end{array}$ & 5.8 & 0.6 \\
\hline $\begin{array}{c}\text { External wall heat transfer } \\
\text { coefficient } / \mathrm{W} /\left(\mathrm{m}^{2} \mathrm{~K}\right)\end{array}$ & 2.6 & 0.55 \\
\hline Roof heat transfer coefficient $/ \mathrm{W} /\left(\mathrm{m}^{2} \mathrm{~K}\right)$ & 1.4 & $26^{\circ} \mathrm{C}$ in summer, $2{ }^{\circ} \mathrm{C}$ in winter \\
\hline Interior design temperature $/{ }^{\circ} \mathrm{C}$ & $26{ }^{\circ} \mathrm{C}$ in summer, $20{ }^{\circ} \mathrm{C}$ in winter & 30 \\
\hline Outdoor air quantity $/ \mathrm{m}^{3} /\left(\mathrm{h}{ }^{*}\right.$ person) & 30 & End: Fan coil unit plus outdoor air unit \\
\hline
\end{tabular}

Based on this office building model, this paper used the software Design Builder to simulate the energy consumption of transformed designs.

Here, it needs to be specified that the model did not simulate the scenario of summer overheating because there was a lack of information on developing measurements for overheating and a lack of data and reporting of overheating in office buildings in Beijing. To offset this issue, the selection of materials considers the thermal mass because heavyweight building materials have thermal masses that can smooth out peaks in temperatures [52]. The selection of materials in Section 3.2.1 addresses this, too. Related cooling strategies and a credible overheating risk assessment must be calculated and developed when data are fully accessible [53,54]. Gaujena et al. [55] demonstrated that modern HVAC systems offer both advanced automatic and manual control possibilities to adjust indoor environment 
parameters. As this research used a typical office building as a simplified scenario to evaluate technical schemes, the overheating issue is not discussed further.

The technical guide for energy-efficient retrofits of public buildings shows the average energy consumption of large office buildings in Beijing as $111 \mathrm{Wh} / \mathrm{m}^{2} \mathrm{a}$, and the energy consumption of the initial model simulated by the software was $102.8 \mathrm{kWh} / \mathrm{m}^{2} \mathrm{a}$. As the relative error was $7.4 \%$, i.e., less than $10 \%$ [56], this model could be considered accurate and reliable.

\subsection{Conceptual Framework Based on the Concept of Sustainability \\ 2.4.1. Conceptual Framework of Sustainability}

The concept of sustainability is a broad global issue comprising various interrelated issues about people, the environment and society [57]. It requires improvement in economic and social living conditions according to a long-term process [58]. It is ultimately suggested that sustainability involves three dimensions: environmental, sociocultural and economic sustainability [58].

\subsubsection{Sustainability in Building Retrofits}

In essence, achieving sustainability in the built environment is recognized as a holistic approach to adapting to environmental, economic and sociocultural concerns [59]. It also represents a new approach for the building sector, based on a rethinking process designed to link the entire implementation of building retrofits to the environment, economy, society and people [59]. Indeed, sustainability can also be achieved by considering respective features during the early stages of the conceptual design process [60]. It involves two aspects, one is maintaining the outcomes, goals and products, and the other is institutionalizing the process [61].

The major criteria for sustainable building retrofits were introduced by Kibert [62] and refer to reducing the resource consumption, reusing the resources, utilizing recycled materials, conserving the natural environment, removing toxins, considering economic efficiency and reinforcing the quality. These are substantially recommended for ensuring sustainable construction. Meanwhile, the main factors for sustainable building projects and facilities encompass four main parameters: reducing the environmental impact, decreasing the resources used, increasing the utility and being more economical. These can be achieved by development objectives that target the environmental impact, energy consumption, external benefits and financial return, respectively [63]. Also, Godfaurd, Derek and George [64] highlighted that sustainable buildings must be developed based on a clear understanding of the main targets of sustainable development for a low-carbon future. Based on the theory of sustainability, Ding's criteria [63] can be categorized as the sustainable development framework of building retrofits shown in Figure 2. 


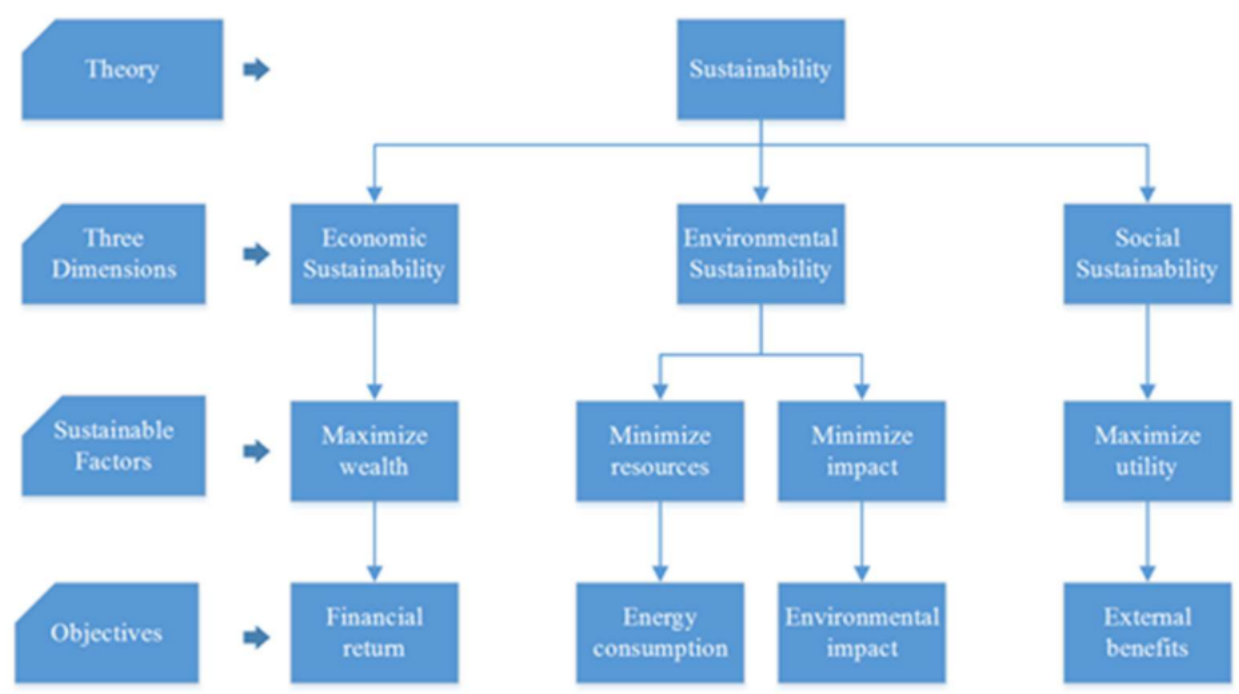

Figure 2. Framework of sustainable development of building retrofits, adapted from ref. [63].

\subsubsection{Operational Framework of Sustainable Buildings' Energy-Efficient Retrofits}

According to the analysis in the last section, sustainable retrofits should focus on three perspectives: financial return, energy consumption/environmental impact and external benefits.

Applying the concept of sustainability, the conceptual framework of sustainable retrofits in existing large office buildings is composed of three elements:

Firstly, external benefits are considered as the overall policy background, where energy conservation is the main way to achieve carbon reduction and neutrality in the building sector, which benefits the whole society. Yet, at present, existing building energy-efficient retrofits are not compulsory and the government only gives the energy-saving label for inspiration, so the benefits that the owners receive for contributing socially cannot be easily quantified. Therefore, this factor is not directly included in the calculations for making decisions in this study.

Technologies are the foundation for developing energy-efficient retrofit schemes. Selecting technical schemes will directly influence the other two elements of the conceptual framework: energy consumption and financial returns.

Energy consumption is one index with which to select energy-efficient retrofit measures and calculate the operating cost savings. These can be calculated by simulating the energy consumption using a typical large office building model and building simulation software. The effects of energy consumption can be transformed into energy-saving benefits as the building retrofit process can reduce negative externalities of energy consumption by building owners.

Financial returns are considered as the profitability of conducting energy-efficient retrofits. The process of selecting retrofit technologies is a decision-making procedure considering the lifecycle costs. The net present value (NPV) and payback period are used to measure profitability. Lifecycle costs combine the retrofit investment, lifecycle operating cost and benefits of lifecycle energy savings.

From this framework, building owners can determine clearly how much they pay in costs and the energy-saving benefits they could receive if they take up combined energysaving retrofitting technologies. The concept of the lifecycle is applied in the whole calculation, and lifecycle energy conservation is transformed into cost savings to enable direct comparison of technical schemes. The conceptual framework of sustainable building energy-efficient retrofitting is shown in Figure 3. 


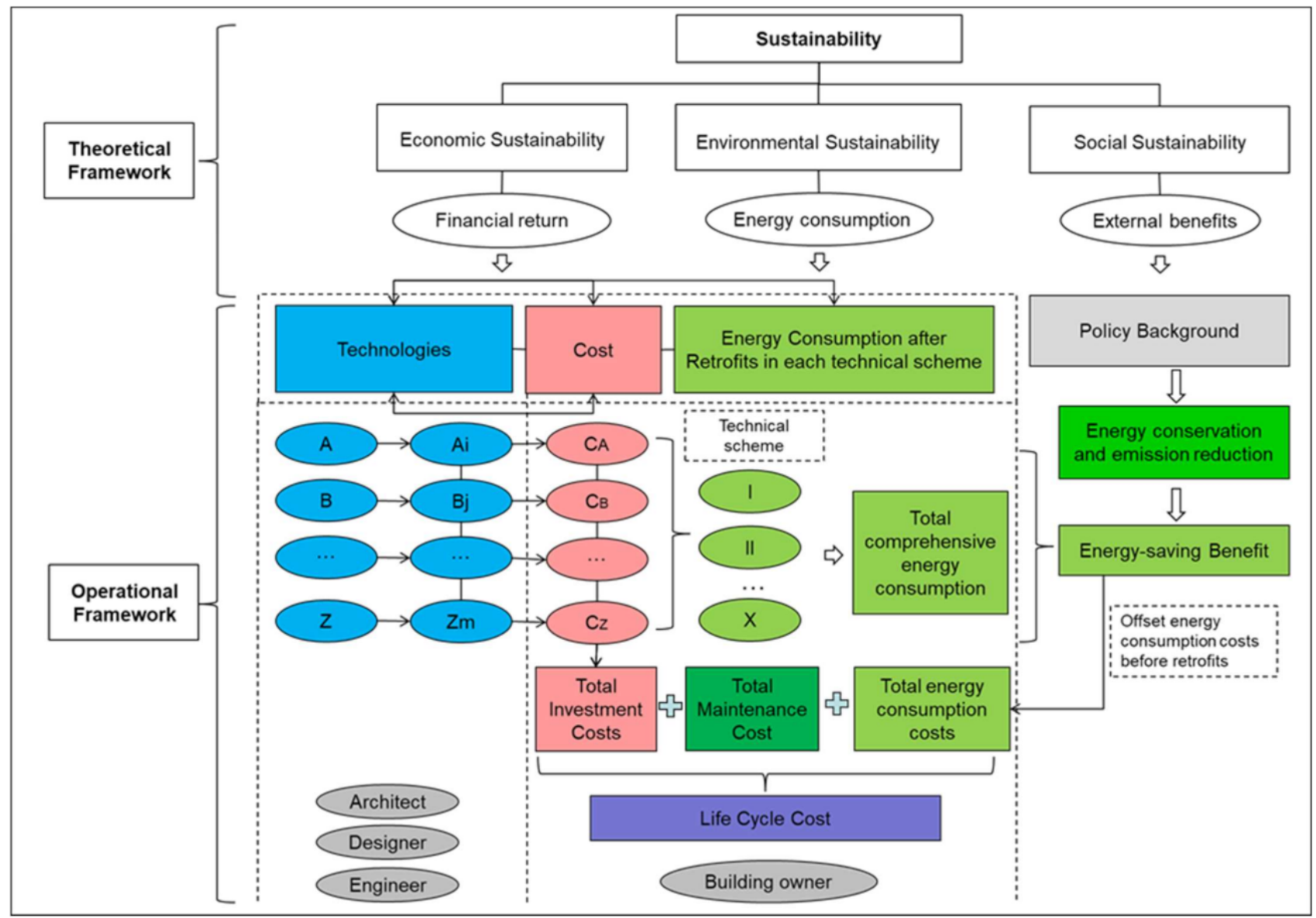

Figure 3. Conceptual framework of sustainable existing-large-office building retrofit.

\section{Materials}

In the annual energy consumption of office buildings, the consumption of heating, ventilation, air conditioning and domestic hot water accounts for about 50-60\%, and lighting uses about $20-30 \%$. About $40 \%$ of the energy for heating, ventilation, air conditioning and domestic hot water is lost by heat transfer to the outdoors, and $30-40 \%$ is occupied with outdoor air treatment [32]. The analysis in this study demonstrated great potential to change that situation in large office buildings by addressing the building envelope, heating, ventilation, air-conditioning and lighting.

\subsection{Current Energy-Efficient Retrofitting Technologies and Energy Saving Potential \\ 3.1.1. Building Envelope}

Over time, the building envelope ages and brings about poor thermal performance, leading to high energy consumption for heating and air conditioning. Related to this, in Beijing, thermal insulation performs poorly, with less than $10 \%$ of large office buildings having adopted external wall thermal insulation technology and nearly $70 \%$ of large office buildings using ordinary single glazing. Moreover, the city suffers for its inordinate pursuit of the external facade effect, using a large proportion of transparent glass curtain walling that creates cold areas of buildings. Also, in Beijing, aluminum alloy window frames are often used, with no thermal insulation measures for these.

Therefore, the reconstruction of external walls and the proper insulation of windows, with replacement hollow double-layer Low-E glass, can greatly reduce the heat lost through the building envelope. After adopting these measures, the air conditioning load can be reduced by $15-45 \%$ and the energy-saving rate of the air conditioning system can reach $15-25 \%$ [40]. 


\subsubsection{Heating, Ventilation and Air Conditioning (HVAC) Systems}

With existing office building air conditioning systems and their actual operating situation, there is a common phenomenon where the selection of cold and heat sources is inefficient. For instance, selecting equipment that is too large, opting for an imbalanced hydraulic, non-adjustable terminal system, making a blind increase of the indoor temperature requirement and operating for too long on part load. The energy consumption of the air conditioning equipment of cold and heat sources accounts for $50-60 \%$ of the total energy consumption, and the water delivery system accounts for a further 20-25\%. For almost $80 \%$ of the operating time of an air conditioning system in a large office building, it is running at under $50-60 \%$ of the design load, so there is a great energy-saving potential for an air conditioning system [40].

\section{Cold and heat sources of building}

There are mainly three problems with the cold and heat sources of large office buildings in Beijing: the chiller and boiler are too large, the inlet and outlet temperature difference of the cold water chiller is small and the operating strategy for the water chiller is unreasonable.

Therefore, through using efficient boilers and refrigeration equipment and improving the automatic control measures for cold and heat sources, it is possible to realize equipment control based on the actual energy demand. The energy storage of air conditioning technology can play the roles of transferring the optimum electricity (up to $50-100 \%$ ), balancing the difference of peak valley and improving the turbine efficiency and economic efficiency. Combining cold air distribution with an air conditioning water system can reduce 10-30\% of the energy consumption of the air conditioning system [40].

\section{Heating, air conditioning, transmission and the terminal system}

There are four main problems with the terminal systems of large office buildings in Beijing: the system is nonadjustable and has no heat recovery device; part of the outdoor air system experiences a blockage and cannot meet wind requirements; the fan coil water system is not equipped with an electric two-way valve; the fan power's consumption is too great and there are no frequency conversion measures.

Accordingly, four measures can be taken to implement energy-efficient retrofits:

Firstly, solve the hydraulic balance problem by balancing measures, which can save about $15 \%$ of the coal and electricity used.

Secondly, adopt frequency-conversion control technology, meaning the energy-saving rate of the air conditioning water system can reach $10-50 \%$.

Thirdly, strengthen the end-regulation measures. According to spot checks and examinations of a typical room, it was found that the water pipe and solenoid valve of the fan coil unit switch did not work, with the result that although the staff had turned off the wind turbine coils, the chilled water was still circulating in the coil for the room. Increasing the chilled water flow of the system will increase the energy consumption of the chiller pump. For the fan coil system, a "wind authority" measure should be adopted for an energy-saving rate of $4 \%$. The modular air handling unit, electric valve and solenoid valve of the fan coil water system should also be checked to see if they can play a role.

Finally, setting up a total heat exchanger in the exhaust air can reduce $55 \%$ of the cold and hot air conditioning load from the outdoor airflow.

\subsubsection{Lighting Systems}

There are three main problems with the electrical system, lighting and office equipment of large office buildings in Beijing: the load rate of the transformer is low, the air conditioning control system is imperfect and efficient energy-saving lamps are not widely used.

Accordingly, an energy-saving retrofit can be carried out for the following aspects: using an energy-efficient light source to reduce the lighting power density value; adjusting the lighting control circuit and turning off the lamps on the sides of windows when the illumination is strong, to make full use of the light-penetration glass curtain wall; increasing 
the light sources on work stations and reducing the lighting sources in large areas; turning off the lights when they are not in use, and turning on the lights when needed. After adopting the above measures, the lighting power can be reduced to achieve an energysaving rate of about $5 \%$ under the premise of guaranteeing the work.

\subsubsection{Summary}

According to the analysis of the situation for existing large office buildings in Beijing, this section summarized the potential for energy-saving renovation of existing large office buildings in Beijing, as outlined in Table 3.

Table 3. Present situation and potential analysis of existing large office buildings in Beijing.

\begin{tabular}{|c|c|c|c|c|}
\hline System & Content & Current Level & $\begin{array}{c}\text { Direction of } \\
\text { Energy-Efficient } \\
\text { Retrofit }\end{array}$ & $\begin{array}{c}\text { Strategy of } \\
\text { Energy-Efficient } \\
\text { Retrofit }\end{array}$ \\
\hline \multirow{2}{*}{ Building envelope } & \multirow{2}{*}{$\begin{array}{c}\text { Reduce energy } \\
\text { demand, improve } \\
\text { natural lighting, lower } \\
\text { heat loss and enhance } \\
\text { thermal comfort }\end{array}$} & $\begin{array}{l}\text { Sintering sludge } \\
\text { common brick }\end{array}$ & $\begin{array}{c}\text { Insulate the exterior } \\
\text { wall and roof }\end{array}$ & $\begin{array}{l}\text { Adopt thermal } \\
\text { insulation block with } \\
\text { good thermal } \\
\text { performance }\end{array}$ \\
\hline & & $\begin{array}{c}\text { Aluminum alloy single } \\
\text { glass window }\end{array}$ & $\begin{array}{c}\text { Replace the outer } \\
\text { window }\end{array}$ & $\begin{array}{l}\text { Convert to a Low-E } \\
\text { glass window, double } \\
\text { glazing or take other } \\
\text { airtight measures }\end{array}$ \\
\hline HVAC & $\begin{array}{l}\text { Update the energy } \\
\text { supply mode and } \\
\text { energy system }\end{array}$ & $\begin{array}{l}\text { Low efficiency of the } \\
\text { central air conditioning } \\
\text { system }\end{array}$ & $\begin{array}{l}\text { Retrofit the central air } \\
\text { conditioning system }\end{array}$ & $\begin{array}{l}\text { Build heating and } \\
\text { cooling system and } \\
\text { energy consumption } \\
\text { measuring system }\end{array}$ \\
\hline Electric lighting system & $\begin{array}{l}\text { Reduce the energy } \\
\text { consumption of } \\
\text { lighting and other } \\
\text { office appliances }\end{array}$ & $\begin{array}{c}\text { No energy-saving } \\
\text { lighting equipment and } \\
\text { no energy-saving } \\
\text { control lighting device }\end{array}$ & $\begin{array}{c}\text { Reinstall the circuit and } \\
\text { use energy-efficient } \\
\text { appliances }\end{array}$ & $\begin{array}{l}\text { Reconstruct LED } \\
\text { lighting system and } \\
\text { light pipe }\end{array}$ \\
\hline
\end{tabular}

\subsection{Measures of Energy-Efficient Retrofits \\ 3.2.1. Building Envelope}

\section{External wall}

As a rule, the interior walls of an office building are preserved in a retrofit, with exterior and interior thermal insulation technologies for the external walls usually adopted. In cold regions, interior thermal technology adopted for external wall insulation in parts of the thermal bridge of the building surface has easily generated dew and become wet, even leading to mildew. When this technology has been adopted in parts of the foundation walls and at the insulation layer interface, it has also been prone to causing water vapor condensation. Therefore, it may be that exterior thermal insulation technology should be used instead of interior thermal insulation for the external walls. According to the EBEBRY [38] and considering the thermal mass [52], exterior insulation of the external wall in a cold area mainly uses a thin plaster external thermal insulation system and gives priority to sticking insulation board (thin plaster). There are several commonly used thermal insulation materials, and their performances are shown in Table 4. 
Table 4. Thermal performance of external wall thermal insulation material applied in an office building.

\begin{tabular}{ccccc}
\hline Material Name & $\begin{array}{c}\text { Extracellular } \\
\text { Polysaccharide } \\
\text { Board (EPS Board) }\end{array}$ & $\begin{array}{c}\text { Polyurethane Rigid } \\
\text { Polyurethane (PU) }\end{array}$ & $\begin{array}{c}\text { Extruded } \\
\text { Polystyrene Board } \\
\text { (XPS Board) }\end{array}$ & $\begin{array}{c}\text { Phenol } \\
\text { Formaldehyde } \\
\text { Board (PF Board) }\end{array}$ \\
\hline Apparent density, $\mathrm{kg} / \mathrm{m}^{3}$ & $18-22$ & $25-45$ & $25-35$ & $50-60$ \\
Thermal conductivity, $\mathrm{W} /(\mathrm{m} \times \mathrm{K})$ & $\leq 0.041$ & $\leq 0.024$ & $\leq 0.030$ & $\leq 0.035$ \\
\hline
\end{tabular}

\section{External window}

Existing buildings with single glass windows (curtain walls) are not energy efficient. In general, a retrofit requires the complete replacement of windows that have only a small use-value, serious deformation, poor airtightness or an old appearance. Alternative energysaving windows are hollow glass plastic windows, hollow glass heat insulation aluminum alloy windows, Low-E hollow glass plastic windows, Low-E hollow glass heat insulation aluminum alloy windows and so on [38].

\subsubsection{Heating, Ventilation and Air Conditioning (HVAC) Systems}

\section{Cold and heat sources}

(1) Selection technology of air conditioning cold and heat sources

The cold and heat sources of the air conditioning system are generally equipped with centralized hot- and cold-water heating units, heating and heat exchange equipment. At present, the cold sources are mainly lithium bromide chillers, screw chillers, centrifugal chillers and piston chillers. The heat sources commonly use an urban heat supply network, coal-fired boiler, gas/fuel boiler, heat pump and so on [38]. The cooling and heating system of the central air conditioning system of a large office building can become significantly more economical through an energy-saving retrofit, but compared with a new building, the cost of replacing cold and heat source equipment is relatively high. The retrofit of the cold and heat source should comply with the relevant provisions of the "Technical Standards for Energy Saving of Public Buildings JGJ176-2009" and "Public Building Energy-Efficiency Design Standards GB50189". The refrigeration performance factors for equipment type selection are shown in Table 5.

Table 5. Refrigeration performance coefficient of cold- and heat-source equipment.

\begin{tabular}{|c|c|c|c|}
\hline Type & & $\begin{array}{c}\text { Nominal Refrigerating } \\
\text { Capacity }(C C ; k W)\end{array}$ & $\begin{array}{l}\text { Performance Coefficient } \\
\text { (COP) in Cold Area (W/W) }\end{array}$ \\
\hline \multirow{7}{*}{ Water-cooling } & Piston/scroll & $\mathrm{CC} \leq 528$ & 4.10 \\
\hline & \multirow{3}{*}{ Screw } & $C C \leq 528$ & 4.70 \\
\hline & & $528<\mathrm{CC} \leq 1163$ & 5.10 \\
\hline & & $\mathrm{CC}>1163$ & 5.50 \\
\hline & \multirow{3}{*}{ Centrifugal } & $\mathrm{CC} \leq 1163$ & 5.20 \\
\hline & & $1163<\overline{\mathrm{CC}} \leq 2110$ & 5.50 \\
\hline & & CC $>2110$ & 5.80 \\
\hline \multirow{4}{*}{$\begin{array}{c}\text { Air-cooled or } \\
\text { evaporative cooling }\end{array}$} & \multirow{2}{*}{ Piston/scroll } & $\mathrm{CC} \leq 50$ & 2.60 \\
\hline & & $\mathrm{CC}>50$ & 2.80 \\
\hline & \multirow{2}{*}{ Screw pole } & $C C \leq 50$ & 2.80 \\
\hline & & $C C>50$ & 3.00 \\
\hline
\end{tabular}

(2) Retrofit technology of frequency conversion

The design of a chiller or a heat pump is based on the most unfavorable conditions, so the installed capacity is too large to enhance the efficiency of the chiller under a partial load. At night, unless it is summer, the chiller temperature is often lower than the design 
value, and the unit efficiency will be reduced when the compressor operating point is adjusted by reducing the load or by thermal bypass. In this context, a frequency-control device can be added to the original chiller or heat pump to improve the unit operation efficiency. The frequency converter can optimize the motor speed and the guide vane opening by controlling the temperature difference of the practical and set values of the outlet for chilled water and compressor head, which can limit the unit running speed and improve its efficiency. Doing so can achieve a great energy-saving effect whenever it is used with a full load, some negative pressure or there is a low cooling-water temperature.

\section{Transmission and distribution system}

The central air conditioning system has many disadvantages, such as low fan efficiency, a large selection of equipment and improper control methods. In practice, there are two ways to adjust the fan volume: by changing the pipe network characteristic curve (throttling adjustment) and changing the fan performance curve (speed regulation) [22]. The VAV system has many forms and control modes, and the operating state of the system is complicated. In the actual operation, double-speed or variable-speed fans can be adopted to ensure the minimum indoor air volume. When the variable-speed fans do not work or the retrofit cost is too high, a high-efficiency blower can be used as a replacement.

\section{Terminal system}

(1) New wind and adjustable outdoor air technology

Outdoor air cooling refers to using outdoor low-temperature air to deal with the indoor cold load during the transition season (spring and autumn). It is one of the ways to make rational use of natural cold sources for cooling.

(2) Exhaust air heat recovery technology

The energy contained in the exhaust air conditioner is considerable, and the cold energy can be recovered by an exhaust heat recovery device, which can effectively reduce the cold and hot loads of outdoor air and has good energy-saving and environmental benefits. Therefore, in the retrofit of an air conditioning system, installing a reasonable exhaust heat recovery device can do a lot to help. At present, the common methods of exhaust air heat recovery are using a rotary full heat exchanger and heat recovery system, heat recovery ring, heat pump energy recovery and plate-fin heat exchanger.

\subsubsection{Lighting System}

The most common lighting sources in a large office building are fluorescent lamps, including straight tubular fluorescent lamps and compact fluorescent lamps. At present, the commonly used compact fluorescent light effect is $50-70 \mathrm{~lm} / \mathrm{W}$ and the life is 5000 8000 h. A Tricolor T5 fluorescent lamp's lighting effect can reach $90-110 \mathrm{~lm} / \mathrm{W}$ and the life expectancy is $8000-12,000 \mathrm{~h}$, while the general color rendering index is above 80 [38]. In addition, the market also has high-frequency $\mathrm{T} 8$ fluorescent lamp products, with light effects that can reach more than $100 \mathrm{~lm} / \mathrm{W}$, equal to the performance of three primary color T5 fluorescent lamps.

At the same time, in recent years, semiconductor lighting technology has been developed rapidly and has begun to enter the field of general lighting. The luminous efficiency of LED bulbs can reach over $60 \mathrm{~lm} / \mathrm{W}$, which is about six times that of the traditional incandescent lamp. The system performance of some LED lamps has exceeded $100 \mathrm{~lm} / \mathrm{W}$. At present, all large office buildings can use efficient LED lamps.

\subsection{Technical Variants and Combinations}

According to the analysis of the energy-saving technology of large office buildings in Beijing mentioned above, the energy-saving technologies studied in this paper are shown in Tables 6-8. 
Table 6. Energy-efficient retrofitting technologies for the envelope of typical large office buildings in Beijing.

\begin{tabular}{|c|c|c|c|c|c|c|}
\hline Element & Classification & No. & Energy-Saving Technology & $\begin{array}{l}\text { Heat Transfer } \\
\text { Coefficient U }\end{array}$ & Thickness & Cost $\left(¥ / \mathrm{m}^{2}\right)$ \\
\hline \multirow[t]{3}{*}{ External wall } & $\mathrm{A}$ & A1 & EPS board & 0.133 & 0.59 & 78 \\
\hline & & $\mathrm{A} 2$ & XPS board & 0.119 & 0.59 & 75 \\
\hline & & A3 & PU & 0.121 & 0.59 & 100 \\
\hline \multirow[t]{3}{*}{$\begin{array}{l}\text { External } \\
\text { window }\end{array}$} & B & B1 & $\begin{array}{l}\text { Hollow glass thermal } \\
\text { insulation aluminum alloy } \\
\text { window } 6+13\end{array}$ & 2.665 & & 210 \\
\hline & & B2 & $\begin{array}{l}\text { Low-E hollow glass thermal } \\
\text { insulation aluminum alloy } \\
\text { window } 3+13\end{array}$ & 1.786 & & 390 \\
\hline & & B3 & $\begin{array}{c}\text { Low-E hollow glass thermal } \\
\text { insulation aluminum alloy } \\
\text { window } 3+6\end{array}$ & 2.47 & & 340 \\
\hline
\end{tabular}

Table 7. Energy-efficient retrofitting technologies for the HVAC system of typical large office buildings in Beijing.

\begin{tabular}{|c|c|c|c|c|c|c|c|}
\hline Type & Element & Classification & No. & $\begin{array}{l}\text { Energy-Saving } \\
\text { Technology }\end{array}$ & Efficiency & COP/IPLV & Cost (¥/pcs) \\
\hline \multirow[t]{2}{*}{$\begin{array}{l}\text { Cold and heat } \\
\text { source system }\end{array}$} & Cold source & $\mathrm{C}$ & $\mathrm{C} 1$ & Water chiller retrofit & & 5.5 & 1 million \\
\hline & & & $\mathrm{C} 2$ & $\begin{array}{l}\text { Frequency } \\
\text { conversion } \\
\text { technology }\end{array}$ & & 3.67 & 45,000 \\
\hline \multirow{2}{*}{$\begin{array}{l}\text { Transmission } \\
\text { and } \\
\text { distribution } \\
\text { system }\end{array}$} & Fan coil unit & $\mathrm{F}$ & $\mathrm{F} 1$ & $\begin{array}{l}\text { Heat recovery } \\
\text { technology }\end{array}$ & & & 70,000 \\
\hline & & & $\mathrm{F} 2$ & $\begin{array}{l}\text { Frequency } \\
\text { conversion } \\
\text { technology }\end{array}$ & $75 \%$ & & 60,000 \\
\hline
\end{tabular}

Table 8. Energy-efficient retrofitting technologies for the lighting system of typical large office buildings in Beijing.

\begin{tabular}{ccccc}
\hline Element & Classification & No. & Energy-Saving Technology & Cost $\left(¥ / \mathbf{m}^{\mathbf{2}}\right)$ \\
\hline Lighting & D & D1 & LED & 120 \\
& & D2 & T5 fluorescent lamp (16 mm) & 90 \\
& D3 & T8 fluorescent lamp (25 mm) & 90 \\
\hline
\end{tabular}

In practice, buildings often use more than one energy-saving technology, most of which combine several technologies. Energy-saving technological development should be extended to a number of technical skills not yet addressed. It is necessary to retrofit energy-saving technology for building envelopes, HVAC systems and equipment and lighting systems, explore how to achieve a comprehensive energy-saving effect and take the mutual influence of different energy-saving technologies into account. According to the analysis of the energy-saving potential of the individual technologies mentioned above, a total of 13 energy-saving technologies may be applied with technological integration. The selected 13 energy-saving technologies may be combined and tailored to obtain an accurate cost-optimal solution. In considering how best to do this, 108 combinations (of three external wall thermal insulation technologies * three external-window thermal-insulation 
technologies * two cold-source energy-saving technologies * two transmission and distribution system energy-saving technologies * and three energy-saving lighting technologies) were simulated by Design Builder software. Based on their energy consumption data and market investigation and installation and repair quota cost estimations in Beijing, this paper calculated the integrated effect of those combinations and their economic costs.

\section{Results and Discussion}

Based on the simulation results for the energy consumption after retrofitting the 108 combinations of technical schemes, further assessment of energy performance and economic analysis were conducted to provide additional detail.

\subsection{Assessment of Energy Performance}

\subsubsection{Energy-Saving Ratio of Energy-Efficient Retrofit}

After the energy-efficient retrofit, the building's energy consumption changed. The energy-saving ratio can be used to evaluate energy efficiency, via the following formula:

$$
\varepsilon=\frac{E-E_{0}}{E_{0}},
$$

where $\varepsilon$ stands for the energy-saving rate, $E$ represents the energy consumption after the energy-efficient retrofit and $E_{0}$ represents the original energy consumption before the energy-efficient retrofit.

According to the technical selection and energy consumption simulation, the effects of the different combinations of energy-efficient retrofitting technologies for a large office building in Beijing are shown in Figure 4.

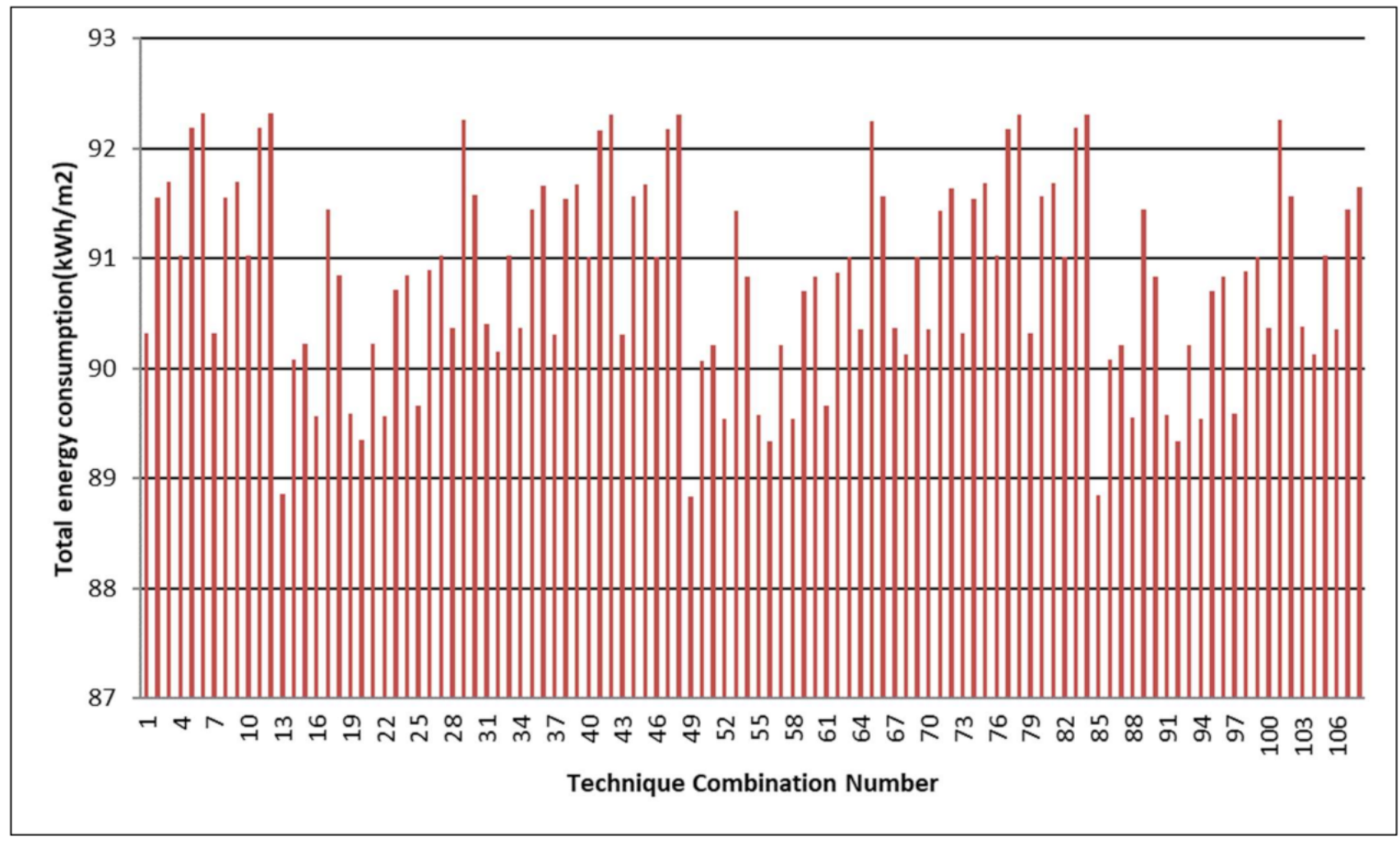

Figure 4. Total energy consumption at end of each technical combination after energy-efficient retrofit. 
Based on the original building's energy consumption, according to the formula to calculate the energy-saving ratio, the energy efficiency rates of the building after applying each combination technique are shown in Figure 5.

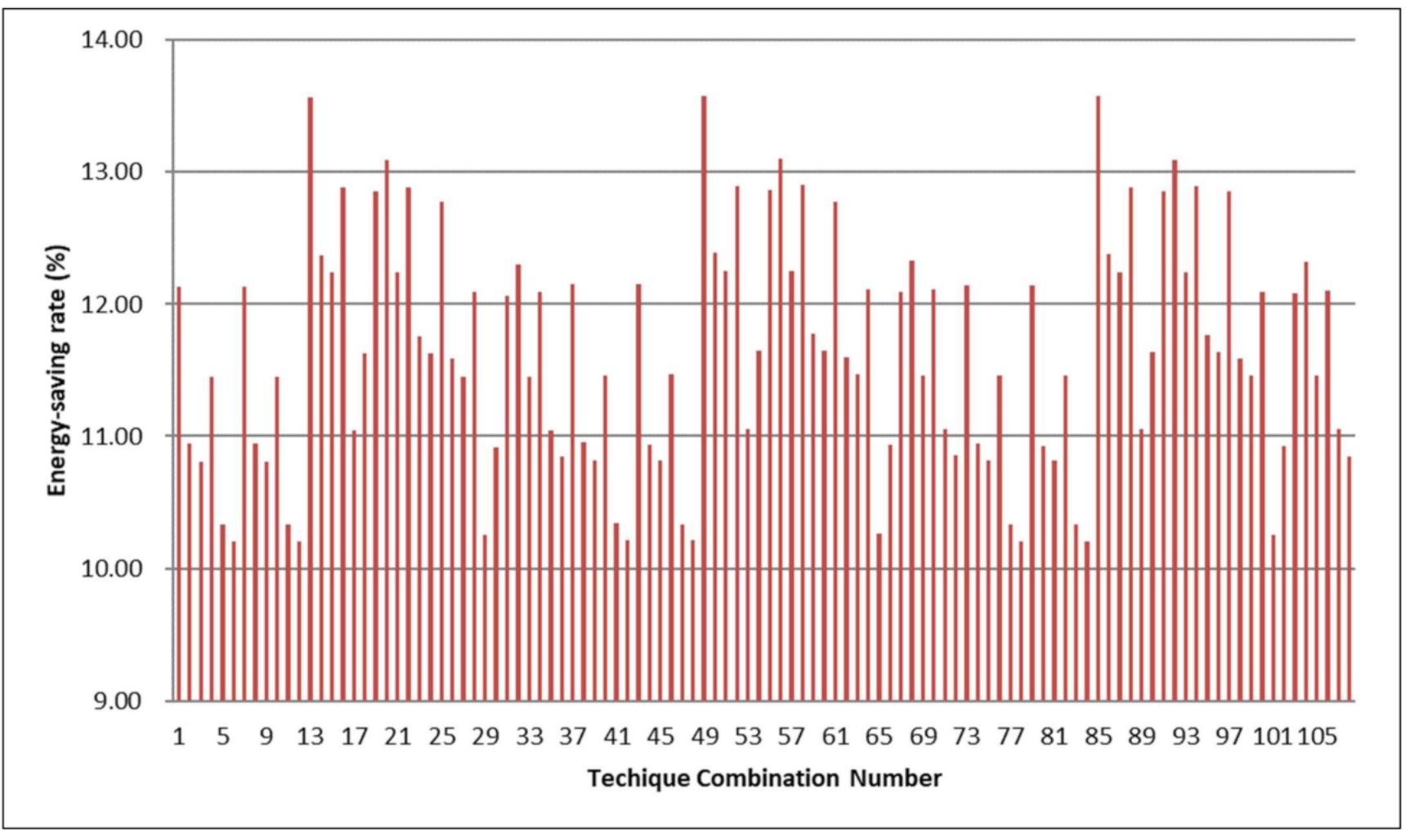

Figure 5. Energy-saving rate of each technical combination after energy-efficient retrofit.

From the above two figures, we can see that combinations 13, 49 and 85 of energyefficiency technologies have a good energy-saving effect, as shown in Table 9. From the table, it can be seen that there are common technologies chosen for energy-efficient retrofits in these three combinations, i.e., the installation of Low-E hollow glass heat aluminum alloy windows (model: $3 \mathrm{~mm}+13 \mathrm{~mm}$ air), high-COP chillers using hot-air exhaust recovery technology, and an LED lighting system. The addition of external wall thermal insulation has little influence on the overall energy consumption. The energy-saving rates of these three technical schemes are over $13 \%$.

Table 9. Arrangement of technology with the highest energy saving rate after energy-efficient retrofit.

\begin{tabular}{|c|c|c|c|c|c|c|c|c|}
\hline C.No. ${ }^{1}$ & $\begin{array}{l}\text { External } \\
\text { Wall }\end{array}$ & $\begin{array}{l}\text { External } \\
\text { Window }\end{array}$ & $\begin{array}{l}\text { Cold } \\
\text { Source }\end{array}$ & $\begin{array}{l}\text { Heat } \\
\text { Source }\end{array}$ & $T \& D^{2}$ & Lighting & $\begin{array}{l}\text { Total End Energy } \\
\text { Consumption } \\
\left(\mathrm{kWh} / \mathrm{m}^{2}\right)\end{array}$ & $\begin{array}{c}\text { Energy-Saving } \\
\text { Rate }(\%)\end{array}$ \\
\hline 13 & A1 & B2 & $\mathrm{C} 1$ & E & F1 & D1 & 88.85415 & 13.57 \\
\hline 49 & A2 & B2 & $\mathrm{C} 1$ & E & F1 & D1 & 88.83945 & 13.58 \\
\hline 85 & A3 & B2 & $\mathrm{C} 1$ & E & F1 & D1 & 88.8468 & 13.57 \\
\hline
\end{tabular}

${ }^{1}$ C.No. $=$ Combination number ${ }^{2} \mathrm{~T} \& \mathrm{D}=$ Transmission and distribution system.

\subsubsection{Lifecycle Retrofitting Composite Cost}

While considering the energy-efficiency effect of a retrofit, it is necessary to pay attention to the cost of the retrofit and the benefit of reducing the energy consumption of the building in the future. So, this research took the cost-effectiveness and cost-economy into consideration. This study considered the costs of investment, annual maintenance 
costs of equipment, the comprehensive costs over time and the costs of energy consumption to represent the total lifecycle costs. The equipment maintenance fees were understood to be $3 \%$ of the investment cost, according to a market investigation. Then, to calculate the economic efficiency of each energy-saving technology, the energy consumption was converted into a unified price according to the simulation of the total energy consumption of the building, the market price of electricity and the market price of natural gas. According to the basic situation for the construction industry, the discount rate was held as $10 \%$. The total lifecycle cost could then be calculated as follows.

$$
C(\tau)=C I+\sum_{j}\left(\sum_{i=1}^{\tau} C_{m}(j) \times(1+r)^{-\tau}\right)+\sum_{j}\left(\sum_{i=1}^{\tau} C_{e}(j) \times(1+r)^{-\tau}\right),
$$

where $\tau$ represents the life period of the building system (the life period without a need to replace the original equipment, but with the installation of a frequency conversion device, was defined as five years, while the span until equipment would need to be replaced was defined as 20 years); $C I$ represents the total costs of restructuring investment; $j$ represents every modification to the building, such as to the building envelope, HVAC system and lighting system; $C_{m}$ represents the annual maintenance costs of the equipment; $C_{e}$ represents the total energy consumption per year of construction (and energy benefits refer to the difference in energy consumption before and after energy-efficient retrofitting); $r$ stands for discount rates.

According to the above calculation, a comprehensive breakdown of the energy-saving rate and costs is shown in Figure 6.

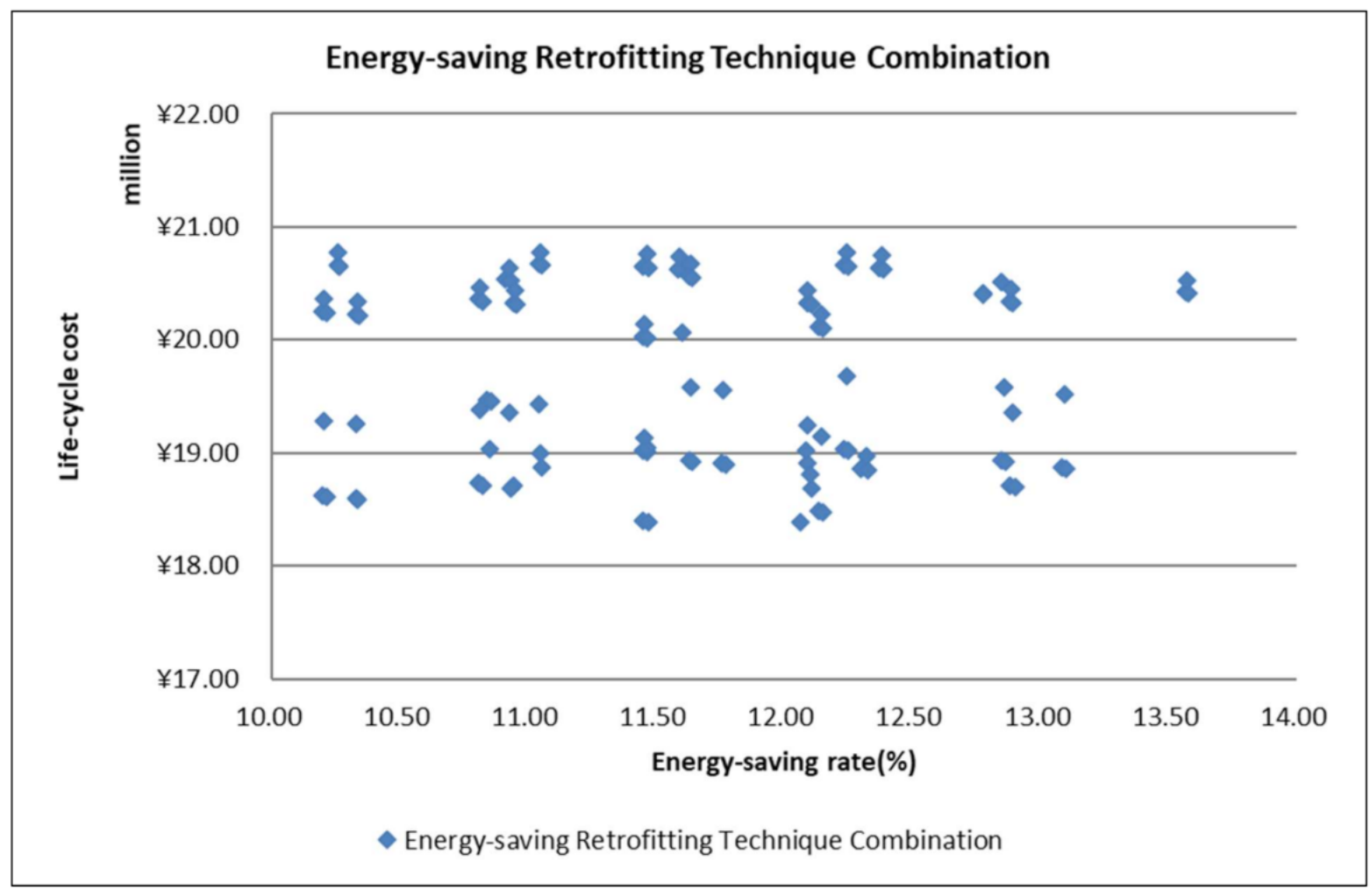

Figure 6. Technical combinations of lifecycle cost and energy-saving ratio.

In Figure 6, we can see that when the lifecycle costs of the building are considered together with the energy-saving rates, combinations 16, 19, 20, 22, 52, 55, 56, 58, 88, 91, 92 and 94 have the better overall energy-saving effect, varying from $12.8 \%$ to $13.2 \%$. Among them, the installation of Low-E hollow thermal insulating aluminum alloy windows (model: $3 \mathrm{~mm}+13 \mathrm{~mm}$ Air) is a common technical choice. In cold-source systems, 75\% opt for 
cooler frequency updates. In lighting systems, 75\% of the technical schemes select LED energy-saving technology. There is little influence of external thermal insulation technology among the technical schemes. Detailed information for the selected technical combinations is shown in Table 10.

Table 10. The optimized technical combined arrangement of cost and energy efficiency after the energy-efficient retrofit.

\begin{tabular}{|c|c|c|c|c|c|c|c|c|}
\hline C.No. & $\begin{array}{l}\text { External } \\
\text { Wall }\end{array}$ & $\begin{array}{l}\text { External } \\
\text { Window }\end{array}$ & $\begin{array}{l}\text { Cold } \\
\text { Source }\end{array}$ & $\begin{array}{c}\text { Heat } \\
\text { Source }\end{array}$ & T\&D & Lighting & $\begin{array}{l}\text { Total End Energy } \\
\text { Consumption } \\
\left(\mathbf{k W h} / \mathbf{m}^{2}\right)\end{array}$ & $\begin{array}{c}\text { Energy-Saving } \\
\text { Rate (\%) }\end{array}$ \\
\hline 16 & A1 & B2 & $\mathrm{C} 1$ & $\mathrm{E}$ & F2 & D1 & 89.55975 & 12.88 \\
\hline 19 & A1 & B2 & $\mathrm{C} 2$ & E & $\mathrm{F} 1$ & D1 & 89.58915 & 12.85 \\
\hline 20 & A1 & B2 & $\mathrm{C} 2$ & E & F1 & D2 & 89.3466 & 13.09 \\
\hline 22 & A1 & B2 & $\mathrm{C} 2$ & E & F2 & D1 & 89.55975 & 12.88 \\
\hline 52 & $\mathrm{~A} 2$ & B2 & $\mathrm{C} 1$ & E & F2 & D1 & 89.54505 & 12.89 \\
\hline 55 & $\mathrm{~A} 2$ & B2 & $\mathrm{C} 2$ & E & F1 & D1 & 89.57445 & 12.87 \\
\hline 56 & A2 & B2 & $\mathrm{C} 2$ & E & $\mathrm{F} 1$ & D2 & 89.3319 & 13.10 \\
\hline 58 & $\mathrm{~A} 2$ & B2 & $\mathrm{C} 2$ & E & F2 & D1 & 89.5377 & 12.90 \\
\hline 88 & A3 & B2 & $\mathrm{C} 1$ & E & F2 & D1 & 89.5524 & 12.89 \\
\hline 91 & A3 & B2 & $\mathrm{C} 2$ & E & F1 & D1 & 89.5818 & 12.86 \\
\hline 92 & A3 & B2 & $\mathrm{C} 2$ & E & F1 & D2 & 89.33925 & 13.09 \\
\hline 94 & $\mathrm{~A} 3$ & B2 & $\mathrm{C} 2$ & E & F2 & D1 & 89.54505 & 12.89 \\
\hline
\end{tabular}

\subsection{Economic Analysis of Energy Reduction Retrofitting Effect}

The economic evaluation of energy-efficient retrofits for existing public buildings mainly required investigating the profitability of the investment in the project and comparing it with the situation before the energy-efficient retrofit. The main economic evaluation indexes used were the NPV and investment payback period.

The NPV is a dynamic evaluation index reflecting the energy-saving benefit in the lifecycle of the building, which is calculated based on the difference between the energysaving benefits and operation costs. According to the selected discount rate, the value at the time of evaluation can be calculated using the investment costs minus the total present value of the benefits for balance.

The formula for calculating the net present value is:

$$
\mathrm{NPV}=\mathrm{CI}-\sum_{t=1}^{n}(C E-C M) \times t \times(1+i)^{-t}
$$

where NPV represents the net present value, $C I$ represents the total investment of building energy-efficient retrofits, $C E$ represents the benefits of energy savings, $C M$ represents the annual maintenance cost of the building, $t$ represents the life expectancy under one technological combination of energy-efficient retrofits and $i$ represents the discount rate.

The dynamic investment payback period is the time taken for the total energy-saving benefits of the building, in the process of use, to compensate for the energy-saving renovation investment. Calculating the overall energy saving benefit involves adding together all kinds of different energy-efficient technologies' impacts. Recovering the investment as soon as possible and reducing the investment costs are two great concerns for investors. The payback period method is simple and easy to use together with net present value, and can help investors to make reasonable investment decisions. The formula for calculating the investment payback period is:

$$
\sum_{t=0}^{P_{t}}(C I-C E+C M) \times t \times(1+i)^{-t}=0
$$

where $C I$ represents the total investment in energy-efficient retrofits, $C E$ represents the benefits of energy savings, CM represents the annual maintenance cost of the building, $t$ represents the life expectancy under one technological combination of energy-efficient 
retrofitting, $i$ represents the discount rate and $P_{t}$ represents dynamic investment recovery period.

According to the chosen technical combination schemes in the previous section, the net present value and dynamic payback period were used to analyze the economic efficiency of the schemes. The results are shown in Table 11.

Table 11. Economic efficiency analysis of the combination of energy-efficient technology in the whole life cycle after retrofitting.

\begin{tabular}{|c|c|c|c|c|c|c|c|c|c|c|c|c|}
\hline C.No. & E.W. ${ }^{1}$ & $\begin{array}{c}\text { E. } \\
\text { WW. }{ }^{2}\end{array}$ & C.S. & H.S. & T\&D & L. ${ }^{5}$ & $\begin{array}{l}\text { Energy } \\
\text { Saving } \\
\text { Benefits } \\
\text { (¥/Year) }\end{array}$ & $\begin{array}{c}\text { Total } \\
\text { Retrofit } \\
\text { Cost }(¥)\end{array}$ & $\begin{array}{c}\text { Annual } \\
\text { Maintenance } \\
\text { Cost of } \\
\text { Equipment } \\
\text { (¥/Year) }\end{array}$ & NPV (¥) & $\begin{array}{c}\text { Dynamic } \\
\text { Payback } \\
\text { Period } \\
\text { (Year) }\end{array}$ & $\begin{array}{c}\text { Total } \\
\text { Lifecycle } \\
\text { Cost }(¥)\end{array}$ \\
\hline 16 & A1 & B2 & $\mathrm{C} 1$ & $\mathrm{E}$ & F2 & D1 & $287,991.33$ & $3,589,132.02$ & $19,577.25$ & $-703,971.66$ & 13.37 & $20,340,499.01$ \\
\hline 19 & A1 & B2 & $\mathrm{C} 2$ & $\mathrm{E}$ & F1 & D1 & $287,351.84$ & $2,289,135.02$ & 6577.25 & $36,103.31$ & 8.15 & $14,303,292.27$ \\
\hline 20 & A1 & B2 & $\mathrm{C} 2$ & $\mathrm{E}$ & F1 & D2 & $292,627.59$ & $2,275,541.52$ & 6441.30 & $82,949.36$ & 7.95 & $14,256,446.23$ \\
\hline 22 & A1 & B2 & $\mathrm{C} 2$ & $\mathrm{E}$ & F2 & D1 & $287,991.33$ & $2,089,138.02$ & 4577.25 & $252,318.81$ & 7.37 & $14,087076.78$ \\
\hline 52 & A2 & $\begin{array}{l}\text { D2 } \\
\text { B2 }\end{array}$ & C1 & $\mathrm{E}$ & $\mathrm{F} 2$ & D1 & $288,311.07$ & $3,574,652.10$ & 19577.25 & $\begin{array}{r}202,0.01 \\
-686,769.59\end{array}$ & 13.30 & $20,323,296.94$ \\
\hline 55 & A2 & B2 & C2 & $\mathrm{E}$ & F1 & D1 & $287,671.58$ & $2,274,655.10$ & 6577.25 & $52,547.91$ & 8.09 & $14,286,847.67$ \\
\hline 56 & A2 & $\begin{array}{l}\text { D2 } \\
\text { B2 }\end{array}$ & $\mathrm{C} 2$ & $\mathrm{E}$ & F1 & $\begin{array}{l}\text { D1 } \\
\text { D2 }\end{array}$ & $292,947.34$ & $2,261061.60$ & 6441.30 & 99393.96 & $\begin{array}{l}0.89 \\
7.89\end{array}$ & $14,240,001.63$ \\
\hline 58 & A2 & B2 & $\mathrm{C} 2$ & E & F2 & D1 & $288,470.94$ & $2,074,658.10$ & 4577.25 & $269,745.75$ & 7.31 & $14,069,649.84$ \\
\hline 88 & A3 & B2 & $\mathrm{C} 1$ & $\mathrm{E}$ & F2 & D1 & $288,151.20$ & $3,695,318.10$ & $19,577.25$ & $-808,796.66$ & 13.76 & $20,445,324.02$ \\
\hline 91 & A3 & B2 & $\mathrm{C} 2$ & $\mathrm{E}$ & F1 & D1 & $287,511.71$ & $2,895,321.10$ & $11,577.25$ & $-599,823.26$ & 10.49 & $14,939,218.85$ \\
\hline 92 & A3 & B2 & $\mathrm{C} 2$ & $\mathrm{E}$ & $\mathrm{F} 1$ & D2 & $292,787.47$ & $2,881,727.60$ & $11,441.30$ & $-552,977.22$ & 10.24 & $14,892,372.80$ \\
\hline 94 & A3 & B2 & $\mathrm{C} 2$ & $\mathrm{E}$ & $\mathrm{F} 2$ & D1 & $288,311.07$ & $2,695,324.10$ & 9577.25 & $-382,625.43$ & 9.67 & $14,722,021.01$ \\
\hline 13 & A1 & B2 & $\mathrm{C} 1$ & $\mathrm{E}$ & F1 & D1 & $303,338.97$ & $3,789,129.02$ & $21,577.25$ & $-790,332.62$ & 13.45 & $20,426,859.97$ \\
\hline 49 & A2 & B2 & C1 & $\mathrm{E}$ & F1 & D1 & $303,658.72$ & $3,774,649.10$ & $21,577.25$ & $-773,130.55$ & 13.38 & $20,409,657.90$ \\
\hline 85 & A3 & $\begin{array}{l}\text { D2 } \\
\text { B2 }\end{array}$ & C1 & $\begin{array}{l}\mathrm{E} \\
\mathrm{E}\end{array}$ & F1 & D1 & $303,498.84$ & $3,895,315.10$ & $21,577.247$ & $-1,495,157.62$ & $\begin{array}{l}13.00 \\
13.82\end{array}$ & $20,531,684.98$ \\
\hline
\end{tabular}

This analysis demonstrated that of the 15 shortlisted technical combinations, six technical schemes had an NPV of greater than 0 . They were combinations 19, 20, 22, 55, 56 and 58. In these technical schemes, installing an LED lighting system and a frequency converter for the electric refrigeration chiller were the common choices. The payback period of investment was then less than 10 years, with it floating in 7-8 years. All of them met the economic evaluation requirements for a large office building in Beijing. Although technical combinations 13, 49 and 85 show greater energy-saving rates, when considering the economic perspective together with this, they were not the optimal technical schemes, having payback periods of over 13 years.

\section{Conclusions}

This study developed an operational framework for stakeholders to use when planning sustainable energy-efficient retrofits of buildings. The operational framework was finetuned based on the conceptual framework of sustainability. The energy consumption, external benefits and financial return were considered as the three main aspects of importance.

In this research, the emphasis on was integrating the selection of energy-efficient technologies with the energy effect and lifecycle costs of retrofits. The energy effect after retrofitting was simulated to understand the comprehensive energy performance when integrating all kinds of energy-efficiency technologies. The energy performances of different combinations of technical schemes were analyzed together with the whole lifecycle costs. The energy-saving rates and energy-saving economic benefits were calculated based on combinations of various energy-efficiency technologies for a model of a typical large office building in Beijing. According to the results of this study, the key findings were as follows:

(1) Energy-saving effects cannot be increased only by adding more energy-efficiency technologies but should instead be considered and balanced by reviewing the overall, comprehensive technical scheme integrating different kinds of energy-efficiency technologies.

(2) Lighting and air conditioning systems have the potential to reduce the energy consumption greatly via all kinds of energy-efficiency technologies. Combined retrofit works on both lighting and air conditioning systems have a mutual influence. Improvements to these can reduce the total energy consumption of the large office building by around 8-13\%. Though changing the setting of the heat exhaust system can help the air-conditioning 
system to consume less energy to a certain extent, the cost-saving over the whole lifecycle is not significant.

(3) Installing an LED lighting system and the frequency conversion device for the water chiller cannot only sufficiently reduce the building's energy consumption but also make it more economical. Different thermal insulation materials for reconstructing the building envelope had no obvious effect on the thermal performance in a comprehensive simulation of technological combinations.

(4) The optimal technical schemes can reduce the total energy consumption by around $13 \%$ and their payback periods are around 7-8 years.

(5) Information on the building's structure and detailed operating information are beneficial to selecting an energy-efficient technical portfolio when conducting retrofits. Especially for large office buildings, there is a high requirement for HVAC and so it is necessary to conduct a comprehensive analysis of technological combinations that will facilitate an optimized air-conditioning system. Considering the specific lifecycles of different items of equipment makes it simple to decide whether to replace these with new equipment or install a frequency conversion device.

This study established a typical building model to simulate and analyze the energy efficiency of various energy-saving combinations. The accuracy of the simulation depended largely on the rationality and representativeness of the model. Establishing a typical large office model depended on a great amount of statistical data. If more accurate and complete data can be collected in the future, that will make the benchmark model more accurate and reliable after correction, and will lead researchers to obtain more convincing results. Moreover, if more data (related to uncertainties or changes influencing the energy use) can be accessed to calibrate the simulation model to make it closer to a real situation, the accuracy and reliability of the model can be improved. The schemes of technical combinations established in this paper involved one from each type of energy-efficient retrofitting system, and we did not analyze the superimposed effect of a number of technologies introduced to one system. This work was close in its scope to the actual energy-efficient retrofits of large office buildings, and was conducive to facilitating more accurate simulation results and conclusions in the future. Furthermore, validation is needed whereby researchers simulate the results using actual project examples, to verify whether the simulated effect is equal to the actual energy performance after retrofitting.

This study selected Beijing as representative of the cold climate region and as a location where many large office buildings are found. Ultimately, we offered a feasible technical plan for stakeholders and demonstrated how we took a holistic operational approach to evaluating the technical schemes, considering the interactions of different kinds of energy systems and their lifecycle costs. The proposed approach may be used as a reference for future research on other climatic zones and types of buildings.

Author Contributions: Methodology, software, original draft preparation, S.W.; supervision, review, editing, G.D. and G.R.; supervision, funding acquisition, Y.L. All authors have read and agreed to the published version of the manuscript.

Funding: This work was supported by the China National Key R\&D Program under grant no. 2018YFC0704300, National Natural Science Foundation of China under grant no. 71871014 and China Scholarship Council under grant No. 20180709009.

Informed Consent Statement: Not applicable.

Data Availability Statement: All the data adopted in this article are from public resources and have been cited with references accordingly.

Conflicts of Interest: The authors declare no conflict of interest. 


\section{References}

1. SCIOPRC (The State Council Information Office of the People's Republic of China). Responding to Climate Change: China's Policies and Actions. 2021. Available online: http://english.scio.gov.cn/whitepapers/2021-10/27/content_77836502.htm (accessed on 15 January 2022).

2. Liu, Y.; Liu, T.; Ye, S.; Liu, Y. Cost-benefit analysis for energy efficiency retrofit of existing buildings: A case study in China. $J$. Clean. Prod. 2018, 177, 493-506. [CrossRef]

3. THUBECRC (Building Energy Conservation Research Center, Tsinghua University). 2020 Annual Report on China Building Energy Efficiency; China Architecture and Building Press: Beijing, China, 2020.

4. THUBECRC (Tsinghua University Building Energy Conservation Research Center). Annual Report on the Development of China's Building Energy Efficiency 2016; China Architecture and Building Press: Beijing, China, 2016.

5. MOHURD (Ministry of Housing and Urban-Rural Development). The People's Republic of China National Standard GB50189-2015, Design Standard for Energy Efficiency of Public Buildings; China Architecture and Building Press: Beijing, China, 2015.

6. EBEBRYB (Editorial Board Of Existing Building Reconstruction Yearbook). Yearbook of Retrofitting of Existing Buildings 2014; China Architecture and Building Press: Beijing, China, 2015.

7. IEA. Transition to Sustainable Buildings; IEA: Paris, France, 2013.

8. Sherlock, L.; Armstrong, A.; Joly, G.; Kelleher, E.; Feng, W.; Zhou, N.; Lu, H.; Liu, X.; Ge, J.; Hou, J.; et al. Constructing a New, Low-Carbon Future: How Chinese Cities Are Scaling Ambitious Building Energy-Efficiency Solutions, C40; Lawrence Berkeley National Laboratory: Berkeley, CA, USA, 2020.

9. THUBECRC (Building Energy Conservation Research Center, Tsinghua University). Annual Report on the Development of China's Building Energy Efficiency 2020; China Architecture and Building Press: Beijing, China, 2020.

10. Nutkiewicz, A.; Choi, B.; Jain, R.K. Exploring the influence of urban context on building energy retrofit performance: A hybrid simulation and data-driven approach. Adv. Appl. Energy 2021, 3, 100038. [CrossRef]

11. Boyano, A.; Hernandez, P.; Wolf, O. Energy demands and potential savings in European office buildings: Case studies based on EnergyPlus simulations. Energy Build. 2013, 65, 19-28. [CrossRef]

12. Aslani, A.; Bakhtiar, A.; Akbarzadeh, M.H. Energy-efficiency technologies in the building envelope: Life cycle and adaptation assessment. J. Build. Eng. 2019, 21, 55-63. [CrossRef]

13. Belany, P.; Hrabovsky, P.; Kolkova, Z. Combination of lighting retrofit and life cycle cost analysis for energy efficiency improvement in buildings. Energy Rep. 2021, 7, 2470-2483. [CrossRef]

14. Li, W.; Koo, C.; Hong, T.; Oh, J.; Cha, S.H.; Wang, S. A novel operation approach for the energy efficiency improvement of the HVAC system in office spaces through real-time big data analytics. Renew. Sustain. Energy Rev. 2020, 127, 109885. [CrossRef]

15. Berardi, U. Stakeholders' influence on the adoption of energy-saving technologies in Italian homes. Energy Policy 2013, 60, 520-530. [CrossRef]

16. Krarti, M.; Deneuville, A. Comparative evaluation of optimal energy efficiency designs for French and US office buildings. Energy Build. 2015, 93, 332-344. [CrossRef]

17. Baranova, D.; Sovetnikov, D.; Borodinecs, A. The extensive analysis of building energy performance across the Baltic Sea region. Sci. Technol. Built Environ. 2018, 24, 982-993. [CrossRef]

18. Ibrahim, H.S.S.; Khan, A.Z.; Attia, S.; Serag, Y. Classification of heritage residential building stock and defining sustainable retrofitting scenarios in Khedivial Cairo. Sustainability 2021, 13, 880. [CrossRef]

19. Pasichnyi, O.; Levihn, F.; Shahrokni, H.; Wallin, J.; Kordas, O. Data-driven strategic planning of building energy retrofitting: The case of Stockholm. J. Clean. Prod. 2019, 233, 546-560. [CrossRef]

20. Pardo-Bosch, F.; Cervera, C.; Ysa, T. Key aspects of building retrofitting: Strategizing sustainable cities. J. Environ. Manag. 2019, 248, 109247. [CrossRef] [PubMed]

21. Zhou, Q.; Qin, X.; Zhan, Z. Economic evaluation of energy saving retrofit of existing buildings based on energy consumption analysis. Archit. Sci. 2010, 08, 53-57.

22. Shadram, F.; Bhattacharjee, S.; Lidelöw, S.; Mukkavaara, J.; Olofsson, T. Exploring the trade-off in life cycle energy of building retrofit through optimization. Appl. Energy 2020, 269, 115083. [CrossRef]

23. Ren, J.; Wang, P.; Jiang, X. Technical and economic evaluation of different energy-saving measures for public buildings. Constr. Sci. Technol. 2012, 10, 48-53.

24. Reddy, S.; Painuly, J.P. Diffusion of renewable energy technologies-Barriers and stakeholders' perspectives. Renew. Energy 2004, 29, 1431-1447. [CrossRef]

25. Tuominen, P.; Klobut, K.; Tolman, A.; Adjei, A.; de Best-Waldhober, M. Energy savings potential in buildings and overcoming market barriers in member states of the European Union. Energy Build. 2012, 51, 48-55. [CrossRef]

26. Kurnitski, J.; Sarri, A.; Kalamees, T.; Vuolle, M.; Niemela, J.; Tark, T. Cost optimal and nearly zero energy performance requirements for buildings in Estonia. Est. J. Eng. 2013, 19, 183-202. [CrossRef]

27. Congedo, P.M.; Baglivo, C.; D'Agostino, D.; Zacà, I. Cost-optimal design for nearly zero energy office buildings located in warm climates. Energy 2015, 91, 967-982. [CrossRef]

28. Shen, Y.; Xu, P.; Sha, H. Efficiency analysis of common building energy saving technology used in existing public buildings. $J$ HVEAC 2013, 2, 104-109. 
29. Kim, J.J. Economic analysis on energy saving technologies for complex manufacturing building. Resour. Conserv. Recycl. 2017, 123, 249-254. [CrossRef]

30. Egiluz, Z.; Cuadrado, J.; Kortazar, A.; Marcos, I. Multi-criteria decision-making method for sustainable energy-saving retrofit façade solutions. Sustainability 2021, 13, 13168. [CrossRef]

31. PRCNBS (People's Republic of China National Bureau of Statistics). National Bureau of Statistics of China. 2016. Available online: http:/ / www.stats.gov.cn/ (accessed on 15 January 2022).

32. Li, Z.; Wang, Q.; Zhao, H. Green Reconstruction Case of Existing Office Building; China Architecture and Building Press: Beijing, China, 2015.

33. Li, Z.; Wang, Q. Examples of Comprehensive Reconstruction of Existing Buildings: 1; China Architecture and Building Press: Beijing, China, 2009

34. Li, Z.; Wang, Q. Example of Comprehensive Reconstruction of Existing Buildings: 2; China Architecture and Building Press: Beijing, China, 2010.

35. Li, Z.; Wang, Q. Examples of Comprehensive Reconstruction of Existing Buildings: 3; China Architecture and Building Press: Beijing, China, 2011.

36. Li, Z.; Wang, Q. Example of Comprehensive Reconstruction of Existing Buildings: 4; China City Press: Beijing, China, 2012.

37. EBEBRY (Editorial Board of Existing Building Reconstruction Yearbook). Yearbook of Retrofitting of Existing Buildings 2010; China Architecture and Building Press: Beijing, China, 2010.

38. EBEBRY (Editorial Board of Existing Building Reconstruction Yearbook). Yearbook of Retrofitting of Existing Buildings 2011; China Architecture and Building Press: Beijing, China, 2011.

39. EBEBRY (Editorial Board of Existing Building Reconstruction Yearbook). Yearbook of Retrofitting of Existing Buildings 2012; China Architecture and Building Press: Beijing, China, 2013.

40. EBEBRY (Editorial Board of Existing Building Reconstruction Yearbook). Yearbook of Retrofitting of Existing Buildings 2013; China Architecture and Building Press: Beijing, China, 2014.

41. Li, Z.; Zhao, H.; Wang, Q. Technical Guidelines for Green Construction of Office buildings; China Architecture and Building Press: Beijing, China, 2016.

42. EBEBRYB, (Editorial Board of Existing Building Reconstruction Yearbook). Yearbook of Retrofitting of Existing Buildings 2018; China Architecture and Building Press: Beijing, China, 2019.

43. EBEBRYB, (Editorial Board of Existing Building Reconstruction Yearbook). Yearbook of Retrofitting of Existing Buildings 2015; China Architecture and Building Press: Beijing, China, 2017.

44. Chen, L. Case Set of comprehensive Performance Improvement and Renovation Project to Existing Public Buildings; China Architecture and Building Press: Beijing, China, 2019.

45. Cucca, G.; Ianakiev, A. Assessment and optimisation of energy consumption in building communities using an innovative co-simulation tool. J. Build. Eng. 2020, 32, 101681. [CrossRef]

46. Budiyanto, M.A.; Nasruddin, N.; Zhafari, F. Simulation study using building-design energy analysis to estimate energy consumption of refrigerated container. Energy Procedia 2019, 156, 207-211. [CrossRef]

47. Chong, A.; Gu, Y.; Jia, H. Calibrating building energy simulation models: A review of the basics to guide future work. Energy Build. 2021, 253, 111533. [CrossRef]

48. Dascalaki, E.; Santamouris, M. On the potential of retrofitting scenarios for offices. Build. Environ. 2002, 37, 557-567. [CrossRef]

49. Jaffal, I.; Inard, C.; Ghiaus, C. Fast method to predict building heating demand based on the design of experiments. Energy Build. 2009, 41, 669-677. [CrossRef]

50. Asadi, I.; Mahyuddin, N.; Shafigh, P. A review on indoor environmental quality (IEQ) and energy consumption in building based on occupant behavior. Facilities 2017, 35, 684-695. [CrossRef]

51. GB50189-2015; Public Building Energy Efficiency Design Standard. China Architecture and Building Press: Beijing, China, 2015.

52. Hub, Z.C. Solutions to Overheating in Homes: Evidence Review; Zero Carbon Hub: London, UK, 2016.

53. Lomas, K.J.; Porritt, S.M. Overheating in buildings: Lessons from research. Build. Res. Inf. 2017, 45, 1-18. [CrossRef]

54. Rahif, R.; Hamdy, M.; Homaei, S.; Zhang, C.; Holzer, P.; Attia, S. Simulation-based framework to evaluate resistivity of cooling strategies in buildings against overheating impact of climate change. Build Environ. 2021, 108599. Available online: https:/ / www.sciencedirect.com/science/article/pii/S0360132321009902 (accessed on 15 January 2022). [CrossRef]

55. Gaujena, B.; Borodinecs, A.; Zemitis, J.; Prozuments, A. Influence of building envelope thermal mass on heating design temperature. IOP Conf. Ser. Mater. Sci. Eng. 2015, 96, 012031. [CrossRef]

56. Xu, W.; Zou, Y. Technical Guide for Energy Saving Reconstruction of Public Buildings; China Architecture and Building Press: Beijing, China, 2010.

57. GhaffarianHoseini, A.; Ibrahim, R.; Baharuddin, M.N.; GhaffarianHoseini, A. Creating green culturally responsive intelligent buildings: Socio-cultural and environmental influences. Intell. Build. Int. 2011, 3, 5-23. [CrossRef]

58. Alnaser, N.W.; Flanagan, R.; Alnaser, W.E. Model for calculating the sustainable building index (SBI) in the kingdom of Bahrain Energy Build. 2008, 40, 2037-2043. [CrossRef]

59. GhaffarianHoseini, A.; Dahlan, N.D.; Berardi, U.; GhaffarianHoseini, A.; Makaremi, N.; GhaffarianHoseini, M. Sustainable energy performances of green buildings: A review of current theories, implementations and challenges. Renew. Sustain. Energy Rev. 2013, 25, 1-17. [CrossRef] 
60. Hoseini, A.G.; Ibrahim, R.; Abdullah, R. Graphical visualization principles for maintaining punctional relativity of spaces during architectural design. ALAM CIPTA Int. J. Sustain. Trop. Des. Res. Pract. 2012, 4, 9-16.

61. Xu, P.; Chan, E.H.W. ANP model for sustainable building energy efficiency retrofit (BEER) using energy performance contracting (EPC) for hotel buildings in China. Habitat Int. 2013, 37, 104-112. [CrossRef]

62. Kibert, C.J. Sustainable Construction: Green Building Design and Delivery; John Wiley \& Sons: Hoboken, NJ, USA, 2016.

63. Ding, G.K. Sustainable construction-The role of environmental assessment tools. J. Environ. Manag. 2008, 86, 451-464. [CrossRef] [PubMed]

64. Godfaurd, J.; Derek, C.-C.; George, J. Sustainable building solutions: A review of lessons from the natural world. Build. Environ. 2005, 40, 319-328. 